Article

\title{
Combining Ability of Early-Maturing Yellow Maize Inbreds under Combined Drought and Heat Stress and Well-Watered Environments
}

\author{
Laouali M. Nasser ${ }^{1}$, Baffour Badu-Apraku ${ }^{2, * \mathbb{C}}$, Vernon E. Gracen ${ }^{3}$ \\ and Hortense N. A. Mafouasson ${ }^{4}$ \\ 1 Institut National de la Recherche Agronomique du Niger, INRAN/CERRA MARADI, Maradi BP 240, Niger; \\ manal12dz@yahoo.fr \\ 2 International Institute of Tropical Agriculture (IITA), IITA (UK) Ltd., 7th floor Grosvenor House, \\ 125 High Street, Croydon CR0 9XP, UK \\ 3 West African Center for Crop Improvement (WACCI), University of Ghana, Legon, \\ PMB LG 30 Legon-Accra, Ghana; vg45@cornell.edu \\ 4 Institut de Recherche Agricole pour le Développement, IRAD, Yaoundé BP 2123, Cameroon; \\ mafouasson@yahoo.fr \\ * Correspondence: b.badu-apraku@cgiar.org; Tel.: +234+810-8482-590
}

Received: 10 September 2020; Accepted: 9 October 2020; Published: 16 October 2020

check for updates

\begin{abstract}
Grain-yield potential of maize (Zea mays L.) is limited by the harsh climatic conditions during dry seasons in the savanna of sub-Saharan Africa (SSA). One hundred and five hybrids derived from diallel crosses involving 15 early-maturing yellow maize inbreds were screened under combined drought and heat stress (CDHS) and well-watered (WW) conditions at four locations representative of the dry savannas of Niger, 2012-2014. The objective of the study was to examine the general combining ability (GCA) effects of the inbred lines and specific combining ability (SCA) of the crosses under CDHS and WW environments, assess yield and stability of the derived hybrids under contrasting environments and investigate inter-relationships among traits of the hybrids under contrasting environments. GCA and SCA effects for grain yield and other measured traits were significant, with preponderance of GCA effects over SCA effects under both the CDHS and WW environments. Inbred ENT 13 possessed positive and significant GCA effects for grain yield under both CDHS and WW environments indicating that the inbred could be used for developing outstanding hybrids with good levels of tolerance to CDHS. This also implied that the inbred line could serve as invaluable genetic resource for introgression of favorable alleles into tropical early-maturing maize populations for accelerated genetic gains from selection for improved grain yield. Hybrids ENT $13 \times$ TZEI 167 and TZEI $157 \times$ ENT 13 were the most stable and among the highest yielding hybrids across research environments. These outstanding hybrids could be tested extensively for commercialization in SSA to improve food security. Plant and ear aspects and days to $50 \%$ silking could be combined with grain yield in a selection index for improvement of yield under CDHS without yield penalties under WW environments.
\end{abstract}

Keywords: combining ability; drought management; heat stress; gene action; Zea mays L.

\section{Introduction}

Maize is a major staple food crop that supports household and national food security in many African countries [1]. Its production in the savannas of sub-Saharan Africa (SSA) is challenged by several major production factors, prominent among which are simultaneous occurrence of drought and heat stress. As a result of the current global climate variability associated with an increase in temperature 
and erratic rainfall patterns, losses in grain yield are anticipated to rise in major maize-producing environments [2], especially in the Sudan and northern Guinea savanna agro-ecologies of SSA. According to Badu-Apraku et al. [3], all the countries in the dry savanna agro-ecological zones of the sub-region experience drought during the growth cycle of maize. In this sub-region, drought causes an average yield loss of 15 percent in grain yield annually [4], including areas where total rainfall is high [5]. NeSmith and Ritchie [6] reported that greater grain yield reduction occurs when drought coincides with flowering and grain-filling stages of maize. According to Pswarayi and Vivek [7], drought may cause a much higher economic loss because in drought-prone environments, the high probability of drought occurrence dissuades farmers from applying adequate levels of fertilizers and using high planting densities.

Drought affects maize production and productivity through reduction in the duration of the rainy season, irregular rainfall distribution patterns and reduced rainfall intensity during the growing season [8,9]. The effects of moisture stress on maize plants include poor crop stand, delay in silking, tassel blasting, leaf firing, barrenness, poor seed set, reduction in kernel size, which ultimately lead to reduction in grain yield [10]. The physical separation and non-synchronous maturation of male and female inflorescences predispose maize to cross-pollination. Under stress conditions (especially water stress), the interval between pollen-shed and silk-emergence increases. The vulnerability of maize to induced drought stress at the crop reproductive stage is usually associated with the separation of the male and female flowers and their exposure to the stress environment [11,12]. These could result in an average yield loss of $20 \%$ to $50 \%$ under drought stress [13,14].

With the advent of climate change in sub-Saharan Africa during the last two decades, heat stress, both alone and in combination with drought have become an increased constraint to maize production [15]. Lobell and Burke [16] demonstrated that an increase in temperature of $2{ }^{\circ} \mathrm{C}$ would result in a greater reduction in maize yields than a decrease in precipitation of $20 \%$. Additionally, studies have revealed the need to incorporate heat tolerance as well as enhanced drought tolerance into the International Institute of Tropical Agriculture (IITA) maize germplasm to reduce yield losses under combined heat and drought stress. Therefore, a program was initiated by the IITA-Maize Improvement Program (MIP) through the Drought Tolerant Maize for Africa (DTMA) Project in 1997.

In contrast to drought research, relatively less research effort had been devoted to breeding specifically for combined heat and drought stress tolerance in maize by the inception of the project on breeding for combined heat and drought stress in 2019. Using the modified drought stress screening method proposed by Badu-Apraku and Fakorede [17], results of genetic studies revealed that both the additive and nonadditive gene actions conditioned the expression of maize traits under drought stress but additive effects were more important than the non-additive component. The implication was that drought tolerance in maize could be improved by recurrent selection and that drought-tolerant inbred lines with good combining ability could be extracted from improved cycles of selection in drought tolerant breeding populations for inbred line development. Several cycles of recurrent selection were effective for improvement of drought tolerance and high-yielding cultivars, as well as several drought-tolerant hybrids have been developed in the IITA-MIP and commercialized in SSA. An important lesson learnt from the drought-tolerant studies covering over three decades of breeding was that the drought tolerant traits had differential responses to the levels of stress severity. Therefore, breeders must determine the level of stress tolerance of the most appropriate germplasm and traits of interest before initiating a breeding program for drought tolerance. In contrast to drought research, no serious effort had been devoted to breeding specifically for heat stress tolerance in the IITA-MIP until 2019 when the program on combined heat and drought (CDHS) stress was initiated. However, earlier studies in the temperate zone had reported on the negative impact of increased growing season temperatures on temperate maize yields. For example, Thompson [18] showed that an increase in temperature from 22 to $28{ }^{\circ} \mathrm{C}$ during the grain filling period in the U.S. Corn Belt resulted in a $10 \%$ yield loss while Badu-Apraku et al. [19] showed a $42 \%$ yield reduction when mean daily temperatures were increased by $6{ }^{\circ} \mathrm{C}$. Muchow et al. [20], reported that heat stress in maize 
was associated with shortened life cycle and reduced light interception [21], increased respiration and reduced photosynthesis [22] and pollen sterility [23,24]. Dupuis and Dumas [25] compared the response of male and female reproductive tissues to heat stress and reported that female tissues had greater tolerance, with pollen production and/or viability identified as the major factors controlling reduced fertilization under high temperatures. However, the period between silk pollination and ovary fertilization in the female reproductive tissues have recently been highlighted as a critical period that controls grain yield under heat stress [26].

Besides drought stress, heat stress resulting from temperatures rising above $30^{\circ} \mathrm{C}$ can cause severe reduction in grain yield of maize because of adverse effects of high temperature on physiological processes [27]. These lead to increased respiration, reduced photosynthesis and shortening of the developmental stages [21,28]. The flowering stage of the maize plant is characterized as the most vulnerable to heat stress, since under such conditions, the female part of the maize plant is less vulnerable compared to the male reproductive part [15]. Like drought stress, high temperature causes tassel blasting, reduces anthesis-silking synchrony, shortens the duration of grain filling period, lowers kernel set and grain weight causing significant reduction in grain yield $[26,29,30]$. According to Badu-Apraku et al. [19], $6{ }^{\circ} \mathrm{C}$ rise in mean daily temperature caused about $42 \%$ grain yield reduction. Similarly, Lobell et al. [31] demonstrated in field trials in southern Africa that temperatures above $30{ }^{\circ} \mathrm{C}$ caused corresponding decrease in maize production. However, the consequences of heat stress are projected to be more devastating in environments prone to drought [32], implying that these areas are expected to encounter the challenges of severe heat stress. Consequently, heat stress occurring both singly and combined with drought is expected to become a major limitation to maize production in SSA [15].

Drought and heat stress could occur at the same time in farmers' fields when rainfall distribution is irregular and the cropping season is hot [14]. Maize yield deficits attributable to CDHS range from $15 \%$ to $40 \%$ and could surpass $70 \%$ [31,33], depending on the timing, duration and severity of the individual stresses. Under such extreme stress conditions, yield losses may be as high as $100 \%$ [21] and could compel farmers to abandon their farmlands [34]. According to Meseka et al. [14], drought stress and CDHS caused 58\% and 77\% shortfall in grain yield, respectively. Similarly, Nelimor et al. [35] reported a grain yield deficit of $46 \%$ under induced drought stress, $55 \%$ under heat stress and $66 \%$ under CDHS, revealing the devastating effects of individual and combination of drought and heat stress on maize yield.

Combining ability may be defined as the potential of an individual inbred line to contribute superior fitness-related traits to hybrid progeny [36]. In maize breeding programs, knowledge of general combining ability (GCA) of inbreds and specific combining ability (SCA) of hybrid combinations as well as the identification and exploitation of heterotic groups, are crucial for successful hybrid production. This is because, information on the type of gene action controlling yield and related traits under stress is key to identifying useful parents and hybrids, as well as designing appropriate strategies for breeding for CDHS tolerant hybrids. This information is obtainable from combining ability studies. Elmyhun et al. [37] studied the type of gene action conferring grain yield and related traits in eight maize inbreds crossed to two testers. The results of the study revealed significant GCA and/or SCA mean squares (or variances) for most measured traits including grain yield, days to anthesis and silking, anthesis-silking, plant and ear aspects and the number of ears per plant, indicating that additive and non-additive gene effects were both important in the inheritance of the measured traits. However, larger SCA mean squares were obtained in most cases, implying that the non-additive genetic effects mainly governed the traits. Similarly, Oyekunle et al. [38] reported higher SCA than GCA mean squares for grain yield of early yellow maize inbreds under contrasting growing conditions, emphasizing the major role of non-additive gene effects in the expression of the measured traits in the progeny. Contrarily, Akinwale et al. [39] observed a major role of additive gene action in determining grain yield in a diallel study of a set of maize inbreds under contrasting growing conditions. Furthermore, Oyekunle and Badu-Apraku [40] reported comparable results for early-maturing white 
and yellow maize inbreds. The implication therefore is that different breeding strategies could be adopted to develop hybrids for the different research environments. Derera et al. [41] showed a greater role of additive and non-additive genetic effects for grain yield under drought and well-watered conditions, respectively. The inconsistencies obtained in gene interaction conferring grain yield in tropical maize germplasm under CDHS have necessitated studies to determine the type of gene action modulating grain yield and related traits in the set of elite maize inbreds used in the present study.

Librando and Magulama [42] and Kanyamasoro et al. [43] reported that heterotic grouping of maize inbred lines with contrasting genetic backgrounds helps in maximizing the exploitation of heterosis for the development of outstanding hybrids. Cairns et al. [15] reported that CDHS tolerance was genetically different from tolerance to individual stresses and tolerance to either stress singly did not confer CDHS tolerance. Therefore, there is a need for rapid advancement to develop maize varieties with tolerance to CDHS to achieve sustained food security in those agro-ecologies in the dry savannas of SSA. However, there is a dearth of information available on the combining ability and type of gene action regulating yield and other important secondary traits of the newly developed IITA early-maturing yellow-endosperm inbred lines under CDHS conditions. There is therefore the need to study the combining ability of this set of new inbred lines. This information is a prerequisite for adopting appropriate breeding strategies to ensure accelerated genetic gains from selection and deciding the best parental combinations for superior CDHS tolerant hybrid development in the IITA-MIP program. Consequently, during the past decade, the MIP-IITA has been engaged in the evaluation and selection of maize inbred lines and hybrids with tolerance to CDHS environments. Through this program, many early maturing maize inbred lines that are well-adapted to the climatic conditions of SSA countries have been identified. However, few studies have been carried out on the combining abilities of the IITA inbred lines under CDHS environments. Such information would be invaluable in developing productive and stable hybrids $[7,39,44,45]$ with tolerance to CDHS for commercialization in SSA. Additionally, combinations between IITA inbreds and elite inbred lines from the International Centre for Maize and Wheat Improvement (CIMMYT) selected under CDHS could result in superior hybrids with CDHS tolerance.

Selection for stress tolerance based on yield performance alone without considering the expression of other appropriate secondary traits has proved ineffective according to Badu-Apraku et al. [4] and Bolaños and Edmeades [46]. Thus, information on secondary traits that contribute significantly to variations in grain yield under CDHS are required by breeders for index selection to guarantee accelerated genetic gains from selection. Therefore, there is an urgent need for studies on trait associations to identify appropriate traits and effective breeding strategies to enhance progress in the improvement of early- maturing yellow-endosperm maize for tolerance to CDHS [47]. This study therefore examined the combining ability effects of 15 early-maturing yellow maize inbred lines developed in IITA and CIMMYT when evaluated under CDHS as well as in well-watered environments. Additionally, the study examined the stability and productivity of selected single-cross hybrids under CDHS and investigated the inter-relationships among studied traits in contrasting research environments.

\section{Materials and Methods}

\subsection{Genetic Materials and Generation of Diallel Crosses}

Fifteen drought tolerant and susceptible, early-maturing, tropical, yellow-endosperm maize inbred lines (Figure 1) selected from the IITA and CIMMYT maize inbred panels were used in the present study (Table 1). The inbred lines were crossed following Griffings' diallel method IV, without parents and assuming no reciprocal effects of parents under CDHS in maize. The crosses were generated at the National Agronomic Research Institute (INRAN) Maradi, Niger in 2012. One hundred and five single-cross hybrids derived from the diallel crosses were evaluated under CDHS as well as WW environments from 2012 to 2014. Four IITA early-maturing single-cross hybrids (TZEI $23 \times$ TZEI 13, 
TZEQI $82 \times$ TZEQI 93, TZEI $16 \times$ TZEI 8 and TZEI $9 \times$ TZEI 16$)$ and an open-pollinated variety (OPV) $\left(\mathrm{P}_{3}\right.$ Kollo) from INRAN, Niger were used as checks in the field evaluations.

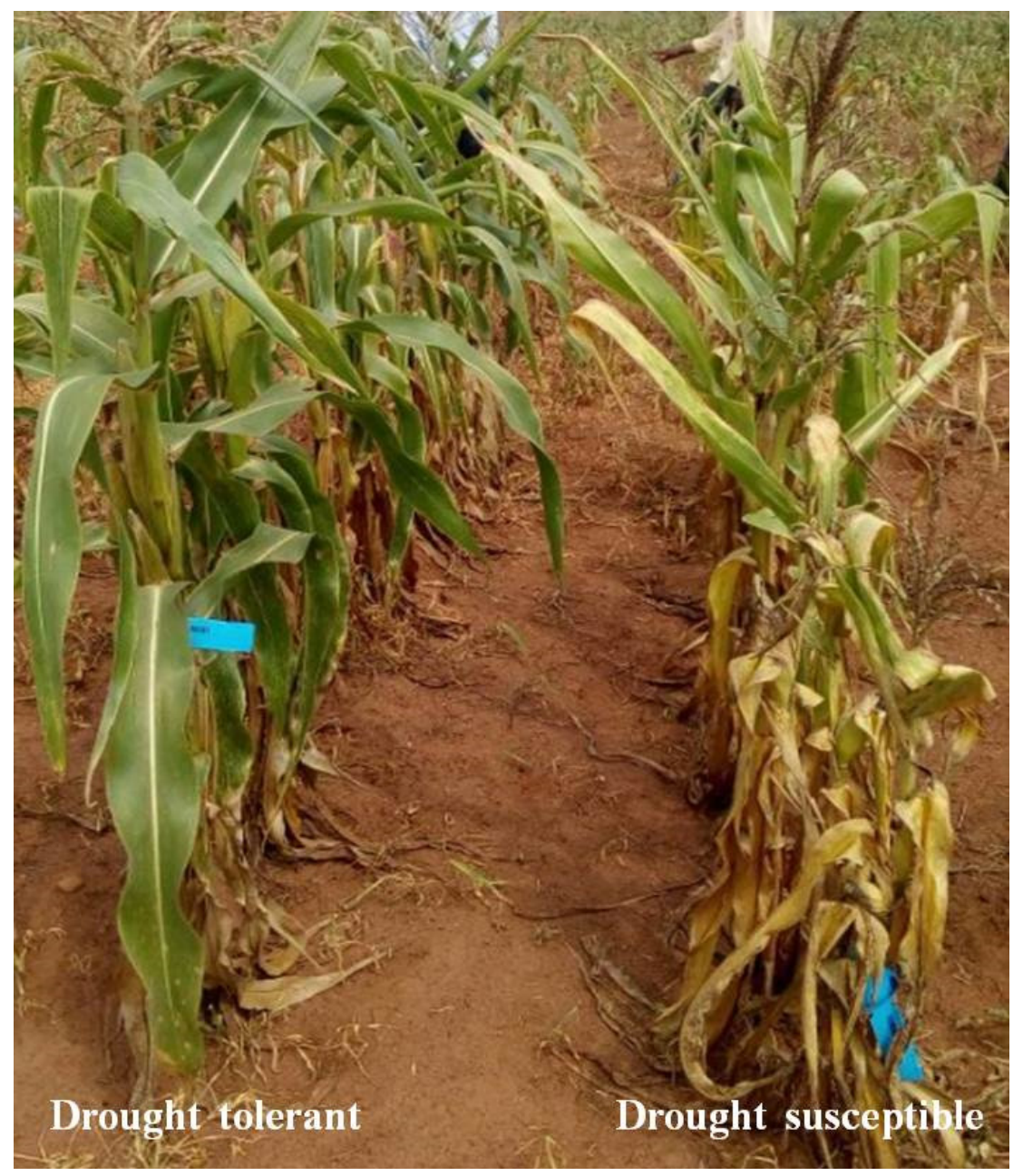

Figure 1. Drought tolerant and drought susceptible inbred lines.

\subsection{Field Evaluations}

The 105 single-cross hybrids plus the 5 checks were assessed under CDHS during the dry seasons of 2012/2013 and 2013/2014 at Konni $\left(13^{\circ} 47^{\prime} \mathrm{N} 5^{\circ} 14^{\prime} \mathrm{E}, 260 \mathrm{~m}\right.$ asl, $530 \mathrm{~mm}$ annual rainfall) and Maradi $\left(13^{\circ} 26^{\prime} \mathrm{N} 7^{\circ} 06^{\prime} \mathrm{E}, 350 \mathrm{~m}\right.$ asl, $490 \mathrm{~mm}$ annual rainfall), respectively. The trials were also evaluated under WW conditions using a furrow irrigation system during the dry season of 2012/2013 at Konni and Maradi and during the rainy season of 2013 at Maradi and FESA Seed Co. $\left(13^{\circ} 39^{\prime} \mathrm{N} 7^{\circ} 04^{\prime} \mathrm{E}\right.$, $382 \mathrm{~m}$ asl; $500 \mathrm{~mm}$ annual rainfall). All trials were evaluated using a $10 \times 11$ randomized incomplete block design with two replications. Each experimental unit was a single-row plot, $5 \mathrm{~m}$ long with inter-row spacing of $0.75 \mathrm{~m}$ and intra-row spacing of $0.40 \mathrm{~m}$. Three seeds were sown per hill and the seedlings later thinned to two at about two weeks after emergence to obtain a population density of approximately $66,667 \mathrm{ha}^{-1}$. Fertilizer was applied at planting in the WW and CDHS trials at a rate of $52 \mathrm{~kg} \mathrm{ha}^{-1}$ each of N, P and K (15-15-15), while an additional $46 \mathrm{~kg} \mathrm{ha}^{-1}$ of urea was top-dressed 20 days after planting. Weed control was done manually at all test sites.

Plants were irrigated twice a week in all blocks from planting till two weeks before flowering. It is worth noting that during the dry season (October to May) in Niger, the weather was so harsh that plants could not have survived if the moisture stress had been imposed from planting until physiological maturity. Therefore, the stress intensity was carefully monitored and a "rescue irrigation" was employed when plants started showing signs of severe drought stress (i.e., leaf rolling, leaf senescence, 
tassel blasting, bending of stems and wilting) very early in the morning (Figure 2). In contrast, irrigation continued in the well-watered blocks until physiological maturity. Apart from the water treatments, all management practices were the similar for both WW and CDHS experiments.

Table 1. Characteristics of 15 early yellow maize inbred lines evaluated in the diallel study under combined drought and heat stress and well-watered environments in Niger, 2012-2014.

\begin{tabular}{|c|c|c|c|c|}
\hline No & Entries & Origin & Pedigree & $\begin{array}{c}\text { Reaction to } \\
\text { Drought Stress }\end{array}$ \\
\hline 1 & ENT 4 & CIMMYT & $\begin{array}{c}\text { [[KILIMA ST94A]-30/MSV-03-2-10-B-1-B-B-xP84c1 } \\
\text { F26-2-2-6-B-3-B] F17-1-2-1-1 } \times \\
\text { P43C9-1-1-1-1-1-BBBB-1-Xp }\end{array}$ & Tolerant \\
\hline 2 & ENT 13 & CIMMYT & [M37W/ZM607\#bF37sr-2-3sr-6- ... 1-B × CML486]-1 & Tolerant \\
\hline 3 & ENT 15 & CIMMYT & CLA149 & Tolerant \\
\hline 4 & ENT 17 & CIMMYT & [(87036/87923)-X-800-3-1-X-1-B-B-1-1-1 & Tolerant \\
\hline 5 & TZEI 14 & IITA & TZE Comp5-Y C6 S6 Inbred 21 & Tolerant \\
\hline 6 & TZEI 16 & IITA & TZE Comp5-Y C6 S6 Inbred 31 & Tolerant \\
\hline 7 & TZEI 129 & IITA & TZE-Y Pop STR Co S6 Inbred 16-1-3 & Susceptible \\
\hline 8 & TZEI 23 & IITA & TZE-Y Pop STR C0 S6 Inbred 62-2-3 & Tolerant \\
\hline 9 & TZEI 124 & IITA & TZE-Y Pop STR Co S6 Inbred 3-1-3 & Susceptible \\
\hline 10 & TZEI 135 & IITA & TZE-Y Pop STR Co S6 Inbred 17-2-3 & Tolerant \\
\hline 11 & TZEI 157 & IITA & TZE-Y Pop STR Co S6 Inbred 102-1-2 & Tolerant \\
\hline 12 & TZEI 161 & IITA & TZE-Y Pop STR Co S6 Inbred 103-2-3 & Tolerant \\
\hline 13 & TZEI 167 & IITA & TZE Comp5-Y C6 S6 Inbred 13 & Susceptible \\
\hline 14 & TZEI 160 & IITA & TZE-Y Pop STR Co S6 Inbred 102-2-3 & Tolerant \\
\hline 15 & TZEI 182 & IITA & TZE-Y Pop STR Co S6 Inbred 152-2-2 & Tolerant \\
\hline
\end{tabular}

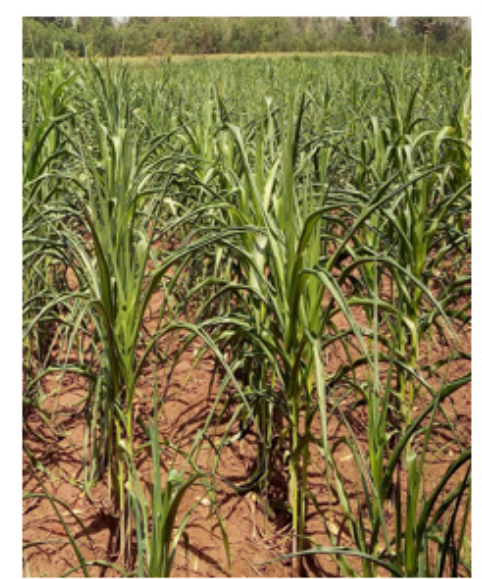

(A). Stressed maize plants under combined drought and heat stress before rescue irrigation.

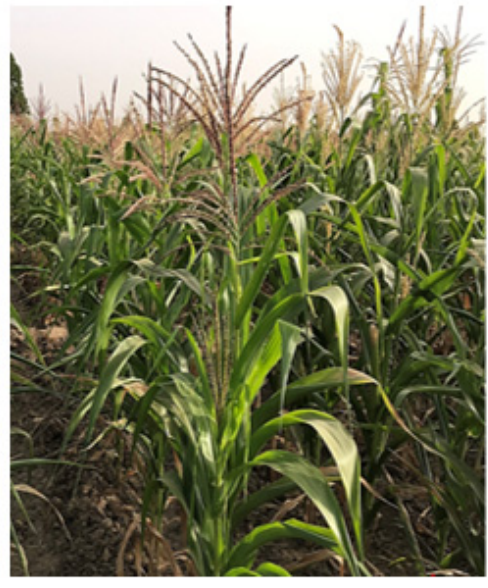

(B). Stressed maize plants under combined drought and heat stress after rescue irrigation.

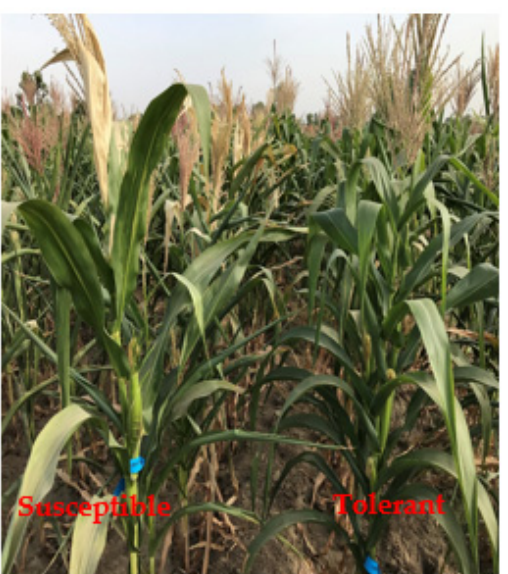

(C). Combined drought and heat stress tolerant and susceptible maize hybrids after flowering.

Figure 2. Reaction of maize plants under combined drought and heat stress.

\subsection{Data Collection}

In the WW and CDHS environments, data were recorded on days to anthesis and silking (DYA and DYS), anthesis-silking interval (ASI), plant and ear heights (PLTH and EHT), husk cover (HUSK), plant and ear aspects and number of ears per plant (EPP), previously described by Badu-Apraku et al. [48]. Plant aspect (PASP) was scored based on the general architectural appeal of 
plants in a plot using a scale of 1 to 5 , where $1=$ excellent overall phenotypic appeal and $9=$ completely undesirable phenotypic appeal. Ear aspect (EASP) was recorded based on the size and uniformity of the ears, extent of grain filling, freedom from insect and disease damage using a scale of 1 to 5 , where $1=$ clean, uniform, large and fully filled ears with no disease/insect damage; and $5=$ only one or no ears. The husk cover (HUSK) was rated on a scale of 1 to 5 , where $1=$ husks tightly arranged and extended beyond the ear tip and $5=$ exposed ear tips.

In addition, under CDHS conditions, data were collected on stay-green characteristic (STGR1 and STGR2) at 90 and $100 \mathrm{DAP}$, on a scale of 1 to 9 , where 1 indicated almost all leaves were green and 9 virtually all leaves were dead. The delay in recording the stay-green characteristic was due to the low night temperature during the dry season in Niger that prolonged the flowering and the maturity periods of plants by 30 to 34 days. Leaf firing (LFR) was recorded on a scale of 1 to 9 as the percentage of plants in a plot with leaf firing symptoms; $1=$ no plant with leaf firing in the plot, $9=$ over 90 percent of plants with leaf firing. Tassel blasting was also recorded as no tassel blast (tassels with normal pollen production) or blasted tassels (tassels which were white, dry and without any pollen). Under the CDHS environments, ears harvested from each plot were shelled and used to determine the percentage grain moisture and weight of shelled kernels. Grain yield $\left(\mathrm{kg} \mathrm{ha}^{-1}\right)$ was computed from the weight of the shelled kernels per plot, adjusted to a moisture content of $15 \%$. Furthermore, grain yield $\left(\mathrm{kg} \mathrm{ha}^{-1}\right)$ of the optimal experiments were estimated from field weight of ears per plot, assuming a shelling percentage of 80 , adjusted to $15 \%$ moisture content.

\subsection{Statistical Analysis}

Analysis of variance (ANOVA) was conducted separately for each test environment using PROC GLM procedure in SAS software, version 9.2 TS2M0 [47]. The data for measured traits were subjected to the Bartlett's test for homogeneity of variances [49]. Since the tests for homogeneity of the variances for the stress environments (location/ year combinations) on one hand and the optimal environments on the other, were not significant, combined ANOVA was performed separately across the three CDHS environments and across the four well-watered environments for grain yield, days to anthesis and silking, anthesis silking interval, plant height, ear height, plant aspect, ear aspect, husk cover and number of ears per plant. The hybrids ( 105 single-cross hybrids and 5 checks) were considered as fixed factors whereas environments, replications and blocks were considered as random factors. Significant means were separated using the least significant difference (LSD). Genetic analysis of the GCA effects of the parents and SCA effects of the crosses as well as the mean squares for each and across research environments followed Griffing's method 4 and model 1 [50], using the DIALLEL-SAS program described by Zhang et al. [51]. Only the crosses (excluding the checks) were used in the diallel analysis. The GCA and SCA effects for grain yield and other measured traits were calculated from the mean values adjusted for the block effects under each research condition and across test environments. The relative importance of GCA and SCA based on the performance of the $\mathrm{F}_{1}$ hybrids was estimated as the ratio:

$$
=\frac{2 \sigma^{2} \mathrm{GCA}}{\left(2 \sigma^{2} \mathrm{GCA}+\sigma^{2} \mathrm{SCA}\right)},
$$

where $\sigma^{2} \mathrm{GCA}$ is the variance of effects obtained from the mean squares of GCA and $\sigma^{2} \mathrm{SCA}$ is the variance of effects derived from the mean squares of SCA [52]. Since the total genetic variation among single-cross progenies equals two times the proportion of genetic variation due to GCA plus the SCA component, the closer this ratio was to unity, the greater the predictability of a specific hybrid's performance based on GCA alone.

The statistical model used for the combined diallel analysis under CDHS and WW environments was as follows:

$$
Y_{\mathrm{ijk}}=\mu+\mathrm{Ee}+g_{\mathrm{i}}+g_{\mathrm{j}}+s_{\mathrm{ij}}+\mathrm{gE} \mathrm{E}_{\mathrm{eg}}+\mathrm{s} \mathrm{E}_{\mathrm{es}}+\varepsilon_{\mathrm{ijk}}
$$


where $Y_{\mathrm{ijk}}$ was the observed measurement for the $i j$ th cross grown in the $k$ th environment; $\mu$ was the grand mean; $g_{\mathrm{i}}$ and $g_{\mathrm{j}}$ were the GCA effects; $s_{\mathrm{ij}}$ was the SCA effects; $\mathrm{gE}_{\mathrm{eg}}$ was the interaction effect between GCA and the environment; $\mathrm{sE}_{\mathrm{es}}$ was the interaction effect between SCA and the Environment and $\varepsilon_{\mathrm{ijk}}$ was the error term associated with the $i j$ th cross evaluated in the $k$ th replication and E environment.

To identify productive single-cross hybrids under combined drought and heat stress conditions, a base index (I) that integrated superior grain yield under CDHS with plant aspect, ear aspect and the stay-green characteristic at $100 \mathrm{DAP}$, short anthesis-silking interval and increased number of ears per plant was adopted [45]. Since each trait was standardized to achieve a mean of zero and a standard deviation of 1 to minimize the effects of different scales, a positive value of I was therefore an indicator of tolerance to CDHS while a negative value indicated susceptibility. The base index was estimated using the following equation:

$$
\mathrm{I}=[(2 \times \text { Yield })+\text { EPP }- \text { ASI }- \text { PASP }- \text { EASP }- \text { STGR2 }] .
$$

The genotype main effect plus genotype $\times$ environment interaction (GGE) biplot analysis was used on the grain yield means adjusted for block effects to obtain information on yield performance and stability of the single-cross hybrids across the seven test environments [53].

The GGE biplot model used was:

$$
Y_{\mathrm{ij}}-\beta_{\mathrm{j}}=\lambda_{1} \xi_{\mathrm{i} 1} \eta_{\mathrm{j} 1}+\lambda_{2} \xi_{\mathrm{i} 2} \eta_{\mathrm{j} 2}+\varepsilon_{\mathrm{ij}}
$$

where $Y_{i j}$ was the genetic value (yield) of the combination (hybrid) between Entry $i$ (hybrid) and Tester $j$ (environment) for the trait of interest; $\beta_{j}$ was the mean of all combinations involving Tester $j ; \lambda_{1}$ and $\lambda_{2}$ were the singular values for PC1 and PC2; $\xi_{\mathrm{i} 1}$ and $\xi_{\mathrm{i} 2}$ are the PC1 and PC2 eigenvectors, respectively, for Entry $\mathrm{i} ; \eta_{\mathrm{j} 1}$ and $\eta_{\mathrm{j} 2}$ are the PC1 and PC2 eigenvectors, respectively, for Tester $\mathrm{j} ; \varepsilon_{\mathrm{ij}}$ was the residual of the model associated with the combination of Entry $i$ and Tester $j$.

The procedure described by Mohammadi et al. [54] was adopted for the sequential path co-efficient analyses, to illustrate the causal relationships among traits assayed under CDHS, WW and across research environments.

Stepwise regression analyses were carried out using the software SPSS version 17.0 [55]. The procedure involved organizing the predictor traits into first, second and third orders based on the respective contributions of the traits to the total variation observed in grain yield with minimized multicollinearity [56,57]. Firstly, all measured traits were regressed on grain yield (the primary trait) and those with significant contributions to grain yield at $p \leq 0.05$ were classified as first order traits. Secondly, each of the traits identified in the first-order category were regressed on other measured traits not in the first order category, to identify significant contributors to grain yield through the first-order traits and this category of traits were classified as second-order traits. This procedure was repeated as applicable to identify traits in subsequent orders. The standardized $b$ values obtained from the stepwise regression analysis provided the estimates of the path coefficients $[54,56,57]$ which were used for the $t$-test to detect significance $(p \leq 0.05)$. Hence, only traits displaying significant path coefficients were retained in the model along with the percentage of variation captured in the dependent variable(s).

\section{Results}

\subsection{Analyses of Variance and Combining Ability Estimates of Grain Yield and Other Traits}

Analyses of variance of grain yield and other agronomic traits assayed separately under CDHS and WW environments revealed significant hybrids $(G)$, environments $(E)$ and hybrids $\times$ environment interaction (GEI) variances (mean squares) for all measured traits with the exception of $E$ for ear aspect and GEI for grain yield, days to silking, plant and ear heights and plant aspect under CDHS 
environments and GEI effects for ear height under WW environments (Table 2). Partitioning the genotypic mean squares into its components revealed significant GCA and SCA variances for all assayed traits under CDHS and WW environments. Similarly, GCA $\times$ E interaction variances were significant for the measured traits under CDHS and WW environments, except for plant aspect under CDHS conditions. Additionally, significant variances of the interactions of SCA $\times \mathrm{E}$ were detected for grain yield, days to silking, anthesis-silking interval, plant height and ear aspects under WW environments. In contrast, significant variances of the interactions of SCA $\times \mathrm{E}$ were obtained for only husk cover under CDHS conditions (Table 2). The GCA effects were greater than the SCA effects for grain yield and other traits assayed under CDHS and WW environments (Figure 3). In all cases, GCA effects contributed more than $80 \%$ of the total genetic variation in the traits compared to the SCA effects (Figure 3).

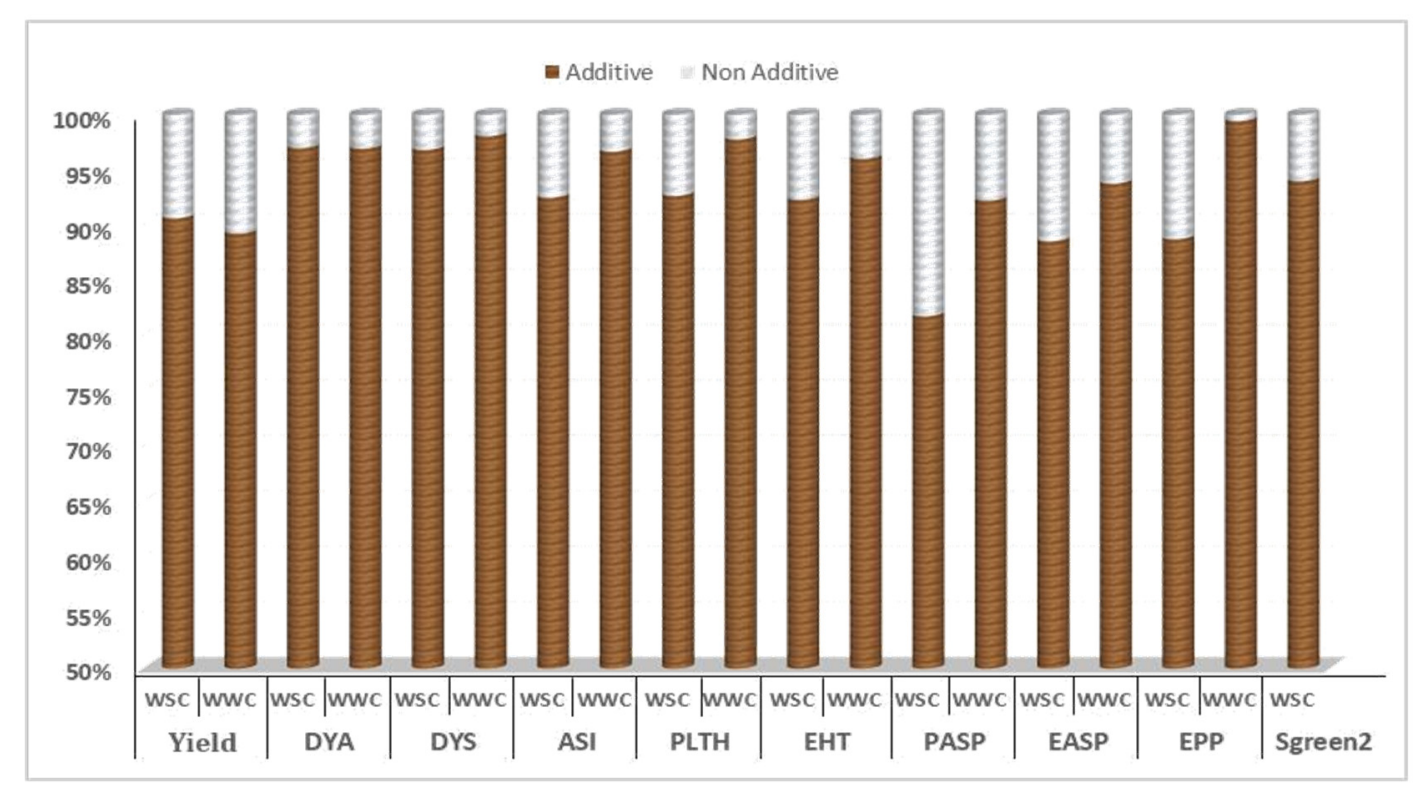

Figure 3. Proportion of additive (lower bar) and non-additive (upper bar) genetic variance for grain yield and other traits of 105 single cross hybrids derived from $15 \times 15$ diallel crosses among 15 early maturing maize inbred lines and evaluated across 3 drought + heat stress environments (WSC) and 4 well-watered condition (WWC).YIELD: grain yield; DYA: days to anthesis; DYS: days to silk; ASI: anthesis-silking interval; PLTH: plant height; EHT: ear height; PASP: plant aspect; EASP: ear aspect; EPP: ear per plant; SGREEN2: stay-green characteristic.

Significant GCA effects were observed for grain yield and other measured traits of the early maturing yellow endosperm inbreds under CDHS and WW environments (Table 3). The GCA effects for grain yield under CDHS environments varied from -320 for TZEI 124 to 472 for ENT 13. However, of the 15 inbreds used in generating the diallel crosses, inbreds ENT 13, TZEI 182 and TZEI 161 had positive and significant GCA effects for grain yield as well as negative and significant GCA effects for the stay green characteristic under CDHS. Under WW environments, GCA effects for grain yield varied from -830 for TZEI 14 to 693 for ENT 13. Significant and positive GCA effects for grain yield were detected for ENT 13, TZEI 124 and TZEI 129 under well-watered environments. ENT 13 was the most outstanding inbred and displayed significant and positive GCA effects for grain yield across the contrasting environments. 
Table 2. Mean squares from the combined diallel analysis of grain yield and other agronomic traits of 105 early maturing yellow endosperm hybrids evaluated under combined drought and heat stress and well-watered environments in Niger from 2012 to 2014.

\begin{tabular}{|c|c|c|c|c|c|c|c|c|c|c|c|c|}
\hline Source of Variation & DF & $\begin{array}{l}\text { Grain Yield } \\
\left(\mathrm{kg} \mathrm{ha}^{-1}\right)\end{array}$ & $\begin{array}{l}\text { Days to } \\
\text { Anthesis }\end{array}$ & $\begin{array}{l}\text { Days to } \\
\text { Silking }\end{array}$ & $\begin{array}{l}\text { Anthesis-Silking } \\
\text { Interval }\end{array}$ & $\begin{array}{c}\text { Plant } \\
\text { Height } \\
\text { (cm) }\end{array}$ & $\begin{array}{c}\text { Ear } \\
\text { Height } \\
(\mathrm{cm})\end{array}$ & $\begin{array}{c}\text { Plant } \\
\text { Aspect }\end{array}$ & $\begin{array}{c}\text { Ear } \\
\text { Aspect }\end{array}$ & $\begin{array}{c}\text { Ears } \\
\text { per } \\
\text { Plant }\end{array}$ & $\begin{array}{l}\text { Husk } \\
\text { Cover }\end{array}$ & $\begin{array}{c}\text { Stay Green } \\
\text { Characteristic } \\
\text { (100 DAP) }\end{array}$ \\
\hline \multicolumn{13}{|c|}{ Combined drought and heat stress environments } \\
\hline Env $^{\dagger}$ & 2 & $33,974,256$ ** & 1732.5 ** & $4 \overline{016.7^{* *}}$ & $675.5^{* *}$ & $4418^{* *}$ & 376 * & $2.5 *$ & $0.7^{\mathrm{ns}}$ & $4.80 * *$ & $18.3^{* *}$ & $106.3^{* *}$ \\
\hline $\operatorname{Rep}($ Env) & 3 & $6,374,226 * *$ & 17.1 * & $153.9 * *$ & $169.9^{* *}$ & $1633^{* *}$ & $591 * *$ & $3.8^{* *}$ & $6.8^{* *}$ & $0.09 \mathrm{~ns}$ & $0.8^{* *}$ & $4.3^{* *}$ \\
\hline Block $(\operatorname{Rep} \times$ Env $)$ & 60 & $1,415,603$ ** & $8.8 *$ & $22.5 * *$ & $14.5^{*}$ & $572.9^{* *}$ & $254^{* *}$ & $1.4^{* *}$ & $1.1^{* *}$ & $0.06^{\mathrm{ns}}$ & $0.2^{\mathrm{ns}}$ & $3.2^{* *}$ \\
\hline Hybrids & 104 & $1,388,241$ ** & $46.4^{* *}$ & $65.4^{* *}$ & $21.7^{* *}$ & $594^{* *}$ & $352 * *$ & $1.4^{* *}$ & $0.9^{* *}$ & $0.09 * *$ & $0.7^{* *}$ & $2.8^{* *}$ \\
\hline GCA & 14 & $4,439,140$ ** & $246.3^{* *}$ & $342.4^{* *}$ & 79.0 ** & $2192 * *$ & $1262 * *$ & $2.7^{* *}$ & $2.5^{* *}$ & $0.26^{* *}$ & $3.0^{* *}$ & $11.4^{* *}$ \\
\hline SCA & 90 & $913,656^{* *}$ & $15.3 * *$ & $22.3 * *$ & $12.8^{* *}$ & $346^{* *}$ & $210 * *$ & $1.2^{* *}$ & $0.6^{* *}$ & $0.07^{\mathrm{ns}}$ & $0.3^{* *}$ & $1.5^{*}$ \\
\hline Env $\times$ Hybrids & 208 & $620,636^{\mathrm{ns}}$ & $6.9^{* *}$ & $14.4^{\mathrm{ns}}$ & $11.3^{*}$ & $207^{n s}$ & $87^{\text {ns }}$ & $0.7^{\mathrm{ns}}$ & $0.5 *$ & $0.07^{* *}$ & $0.3^{* *}$ & $1.4^{*}$ \\
\hline Env $\times$ GCA & 28 & $1,456,065$ ** & $12.6^{* *}$ & $26.8^{* *}$ & $23.3^{* *}$ & $323 *$ & $160^{*}$ & $0.9^{\mathrm{ns}}$ & $0.9^{* *}$ & $0.10^{* *}$ & $0.5^{* *}$ & $2.4^{* *}$ \\
\hline Env $\times$ SCA & 180 & $490,680^{\text {ns }}$ & $6.0^{\mathrm{ns}}$ & $12.5^{\mathrm{ns}}$ & $9.5^{\mathrm{ns}}$ & $189^{\mathrm{ns}}$ & $76^{\mathrm{ns}}$ & $0.6^{\mathrm{ns}}$ & $0.4^{\mathrm{ns}}$ & $0.07^{\mathrm{ns}}$ & $0.2 *$ & $1.3^{\mathrm{ns}}$ \\
\hline Residual & 312 & 531,587 & 5.0 & 12.7 & 8.6 & 206 & 91 & 0.6 & 0.4 & 0.05 & 0.2 & 1.1 \\
\hline \multicolumn{13}{|c|}{ Well-watered environments } \\
\hline Env & 3 & $120,650,005^{* *}$ & $31,206.0^{* *}$ & $29,741.4^{* *}$ & $76.5^{* *}$ & $49,811^{* *}$ & 74,953 ** & $8.2^{* *}$ & $20.4^{* *}$ & $6.26^{* *}$ & $9.2^{* *}$ & \\
\hline $\operatorname{Rep}(E n v)$ & 4 & $7,391,247$ ** & $24.8 * *$ & $34.4 * *$ & $3.1^{\mathrm{ns}}$ & $1325 * *$ & $674 * *$ & $0.7^{\mathrm{ns}}$ & $1.4^{* *}$ & $0.07 *$ & $0.4 *$ & \\
\hline Block $(\operatorname{Rep} \times$ Env $)$ & 80 & $1,880,461$ ** & $3.3^{\mathrm{ns}}$ & $4.1^{\mathrm{ns}}$ & $1.7^{\mathrm{ns}}$ & $137^{\mathrm{ns}}$ & $83^{\text {ns }}$ & $0.5^{*}$ & $0.02^{\mathrm{ns}}$ & 0.30 * & $0.2^{\mathrm{ns}}$ & \\
\hline Hybrids & 104 & $5,555,332 * *$ & $28.1 * *$ & $40.7^{* *}$ & $5.4^{* *}$ & $1570^{* *}$ & 490 ** & $1.7^{* *}$ & $1.6^{* *}$ & $0.07^{* *}$ & $0.9 * *$ & \\
\hline GCA & 14 & $16,217,668$ ** & $148.9 * *$ & $241.1^{* *}$ & $27.9^{* *}$ & $9041^{* *}$ & 2379 ** & $6.1^{* *}$ & $6.6^{* *}$ & $5.25^{* *}$ & $3.2^{* *}$ & \\
\hline SCA & 90 & $3,896,747^{* *}$ & $9.4 * *$ & $9.5^{* *}$ & $1.9^{* *}$ & $408^{* *}$ & $196^{* *}$ & $1.0^{* *}$ & $0.9^{* *}$ & $0.06^{* *}$ & $0.5^{* *}$ & \\
\hline Env $\times$ Hybrids & 312 & $1,296,562$ ** & $4.0 * *$ & $5.9^{* *}$ & $3.0^{* *}$ & $183^{* *}$ & $95^{* *}$ & $0.5^{* *}$ & $0.3^{* *}$ & $0.04^{* *}$ & $0.2^{* *}$ & \\
\hline Env $\times$ GCA & 42 & $3,049,903$ ** & $10.9^{* *}$ & $17.6^{* *}$ & $8.2^{* *}$ & $273^{* *}$ & $254^{* *}$ & $1.1^{* *}$ & $0.6^{* *}$ & $0.04^{* *}$ & $0.5^{* *}$ & \\
\hline Env $\times$ SCA & 270 & $1,023,820$ * & $2.9^{\mathrm{ns}}$ & $4.0 *$ & $2.2 *$ & $169 *$ & $70^{\mathrm{ns}}$ & $0.4^{\mathrm{ns}}$ & $0.2 *$ & $0.02^{* *}$ & $0.1^{\mathrm{ns}}$ & \\
\hline Residual & 416 & 804,728 & 2.5 & 3.2 & 1.7 & 139 & 64 & 0.3 & 0.2 & 0.01 & 0.1 & \\
\hline
\end{tabular}

${ }^{*}, * *-$ Significant at the 0.05 and 0.01 probability levels; ns—not significant; ${ }^{\dagger}$ Env—environment; Rep—replication. 
Table 3. General combining ability effects of grain yield and other agronomic traits of early maturing maize inbred lines under combined drought and heat stress (CDHS) and well-watered environments (WW) in Niger from 2012 to 2014.

\begin{tabular}{|c|c|c|c|c|c|c|c|c|c|c|c|}
\hline \multirow{2}{*}{ Inbreds } & \multicolumn{2}{|c|}{ Grain Yield (kg/ha) } & \multicolumn{2}{|c|}{ Days to Silking } & \multicolumn{2}{|c|}{ Plant Height } & \multicolumn{2}{|c|}{ Plant Aspect } & \multicolumn{2}{|c|}{ Ears per Plant } & \multirow{2}{*}{$\begin{array}{c}\begin{array}{c}\text { Stay Green } \\
\text { Characteristic } \\
\text { (100 DAP) }\end{array} \\
\text { CDHS }\end{array}$} \\
\hline & WW & CDHS & WW & CDHS & WW & CDHS & WW & CDHS & WW & CDHS & \\
\hline TZEI 160 & $-49^{\mathrm{ns}}$ & $114^{\mathrm{ns}}$ & $-1.9^{\mathrm{ns}}$ & $-2.4^{* *}$ & $-12 * *$ & $-4.4^{* *}$ & $0.2 *$ & $-0.07^{\mathrm{ns}}$ & $0.04^{\mathrm{ns}}$ & $0.04^{\mathrm{ns}}$ & $-0.05^{\mathrm{ns}}$ \\
\hline TZEI 129 & $517^{* *}$ & $30^{\mathrm{ns}}$ & $-0.4^{\mathrm{ns}}$ & $-0.1^{\mathrm{ns}}$ & $14^{* *}$ & $7.5^{* *}$ & $-0.1 *$ & $0.03^{\mathrm{ns}}$ & $-0.01^{\mathrm{ns}}$ & $0.08^{*}$ & $-0.14^{\mathrm{ns}}$ \\
\hline ENT 15 & $-109^{\mathrm{ns}}$ & $-286^{* *}$ & $1.6^{\mathrm{ns}}$ & $2.2^{* *}$ & $5 *$ & $0.1^{\mathrm{ns}}$ & $0.1^{\mathrm{ns}}$ & $0.24 * *$ & $-0.03^{\mathrm{ns}}$ & $-0.07^{*}$ & $1.15^{* *}$ \\
\hline ENT 17 & $37^{\mathrm{ns}}$ & $-65^{\mathrm{ns}}$ & $0.7^{\mathrm{ns}}$ & $1.3^{*}$ & $4^{\mathrm{ns}}$ & $-2.5^{\mathrm{ns}}$ & $0.1^{\mathrm{ns}}$ & $-0.02^{\mathrm{ns}}$ & $0.06^{* *}$ & $-0.02^{\mathrm{ns}}$ & $0.23^{\mathrm{ns}}$ \\
\hline TZEI 182 & $-446 * *$ & $333^{* *}$ & $-1.2^{\mathrm{ns}}$ & $-2.6^{* *}$ & $-8^{* *}$ & $0.3^{\mathrm{ns}}$ & $0.2^{* *}$ & $-0.20 *$ & $-0.01^{\mathrm{ns}}$ & $0.07 *$ & $-0.86^{* *}$ \\
\hline TZEI 167 & $-270^{*}$ & $-122^{\text {ns }}$ & $1.4^{\mathrm{ns}}$ & $1.3^{*}$ & $-5^{* *}$ & $-4.4^{* *}$ & $-0.1^{\mathrm{ns}}$ & $0.06^{\mathrm{ns}}$ & $-0.05 *$ & $0.00^{\mathrm{ns}}$ & $0.03^{\mathrm{ns}}$ \\
\hline TZEI 14 & $-830 * *$ & $-210 *$ & $2.6^{*}$ & $3.0 * *$ & $-9^{* *}$ & $-8.3^{* *}$ & $0.2^{* *}$ & $0.16^{\mathrm{ns}}$ & $-0.02^{\mathrm{ns}}$ & $-0.06^{*}$ & $-0.15^{\mathrm{ns}}$ \\
\hline TZEI 124 & $612 * *$ & $-320 * *$ & $-0.3^{\mathrm{ns}}$ & $1.4^{*}$ & $11^{* *}$ & $9.7^{* *}$ & $-0.6^{* *}$ & $0.04^{\mathrm{ns}}$ & $-0.02^{\mathrm{ns}}$ & $-0.12 * *$ & $0.92 * *$ \\
\hline TZEI 16 & $-121^{\mathrm{ns}}$ & $-202 *$ & $2.0^{\mathrm{ns}}$ & $2.0 * *$ & $3^{\text {ns }}$ & $-0.7^{\mathrm{ns}}$ & $0.1^{\mathrm{ns}}$ & $-0.03^{\mathrm{ns}}$ & $0.08^{* *}$ & $0.03^{\mathrm{ns}}$ & $-0.04^{\mathrm{ns}}$ \\
\hline ENT 4 & $-96^{\mathrm{ns}}$ & $-253^{* *}$ & $1.0^{\mathrm{ns}}$ & $2.1^{* *}$ & $3^{\mathrm{ns}}$ & $-0.4^{\mathrm{ns}}$ & $0.1^{*}$ & $0.31^{* *}$ & $-0.01^{\mathrm{ns}}$ & $-0.04^{\mathrm{ns}}$ & $0.63^{* *}$ \\
\hline TZEI 161 & $59^{\mathrm{ns}}$ & $222 *$ & $-1.8^{\mathrm{ns}}$ & $-2.4^{* *}$ & $-7^{* *}$ & $-0.4^{\mathrm{ns}}$ & $0.1^{*}$ & $-0.01^{\mathrm{ns}}$ & $0.00^{\mathrm{ns}}$ & $-0.02^{\mathrm{ns}}$ & $-0.38 *$ \\
\hline TZEI 23 & $-168^{\mathrm{ns}}$ & $151^{\mathrm{ns}}$ & $-2.5^{*}$ & $-3.3^{* *}$ & $-18^{* *}$ & $-8.4^{* *}$ & $0.2^{* *}$ & $-0.06^{\mathrm{ns}}$ & $0.01^{\mathrm{ns}}$ & $0.04^{\mathrm{ns}}$ & $-0.26^{\mathrm{ns}}$ \\
\hline ENT 13 & $693^{* *}$ & $472 * *$ & $0.0^{\mathrm{ns}}$ & $-0.8^{\mathrm{ns}}$ & $13^{* *}$ & $6.2^{* *}$ & $-0.4^{* *}$ & $-0.47^{* *}$ & $-0.01^{\mathrm{ns}}$ & $0.07^{*}$ & $-0.74^{* *}$ \\
\hline TZEI 135 & $-0.1^{\mathrm{ns}}$ & $-20^{\mathrm{ns}}$ & $-0.5^{\mathrm{ns}}$ & $0.1^{\mathrm{ns}}$ & $5^{* *}$ & $2.2^{\mathrm{ns}}$ & $0.1^{\mathrm{ns}}$ & $0.13^{\mathrm{ns}}$ & $-0.01^{\mathrm{ns}}$ & $0.00^{\mathrm{ns}}$ & $-0.19^{\mathrm{ns}}$ \\
\hline TZEI 157 & $172^{\mathrm{ns}}$ & $157^{\mathrm{ns}}$ & $-0.8^{\mathrm{ns}}$ & $-1.9^{* *}$ & $3^{\text {ns }}$ & $3.7^{*}$ & $-0.2 *$ & $-0.10^{\mathrm{ns}}$ & $-0.02^{\mathrm{ns}}$ & $0.03^{n s}$ & $-0.14^{\mathrm{ns}}$ \\
\hline $\mathrm{SE} \pm$ & 43 & 34 & 0.4 & 0.3 & 0.7 & 0.6 & 0.02 & 0.03 & 0.03 & 0.01 & 0.06 \\
\hline
\end{tabular}




\subsection{Performance and Stability of the Single Cross Hybrids across Different Environments}

The significant $G$, E and GEI variances detected for grain yield across CDHS and WW environments prompted the use of GGE biplot to decompose the $G+G \times E$ interactions to examine the yield potential of the single cross hybrids. The results of the GGE biplot analysis involving the 25 diallel crosses (the best-yielding 15 and the worst 10-yielding hybrids selected using the IITA base index) plus five checks evaluated across seven contrasting environments are presented in Figure 4. The GGE biplot analysis revealed that PC1 and PC2 together accounted for $69.3 \%$ of the total variance for grain yield across test environments. The PC1 explained $47.5 \%$ of the total variance while PC 2 explained $21.8 \%$. The GGE biplot was based on genotype- metric preserving $(\mathrm{SVP}=1)$ which is more appropriate for comparing genotypes. The single-arrowed line is the average environment abscissa (AEA) that points to higher mean grain yield across environments. Therefore, the five top-yielding hybrids across test environments in descending order were TZEI $124 \times$ ENT 13, TZEI $167 \times$ ENT 13, TZEI $182 \times$ ENT 13, TZEI $124 \times$ TZEI 23 and TZEI $160 \times$ TZEI 157. The top three yielding hybrids were derived from crosses involving ENT 13.
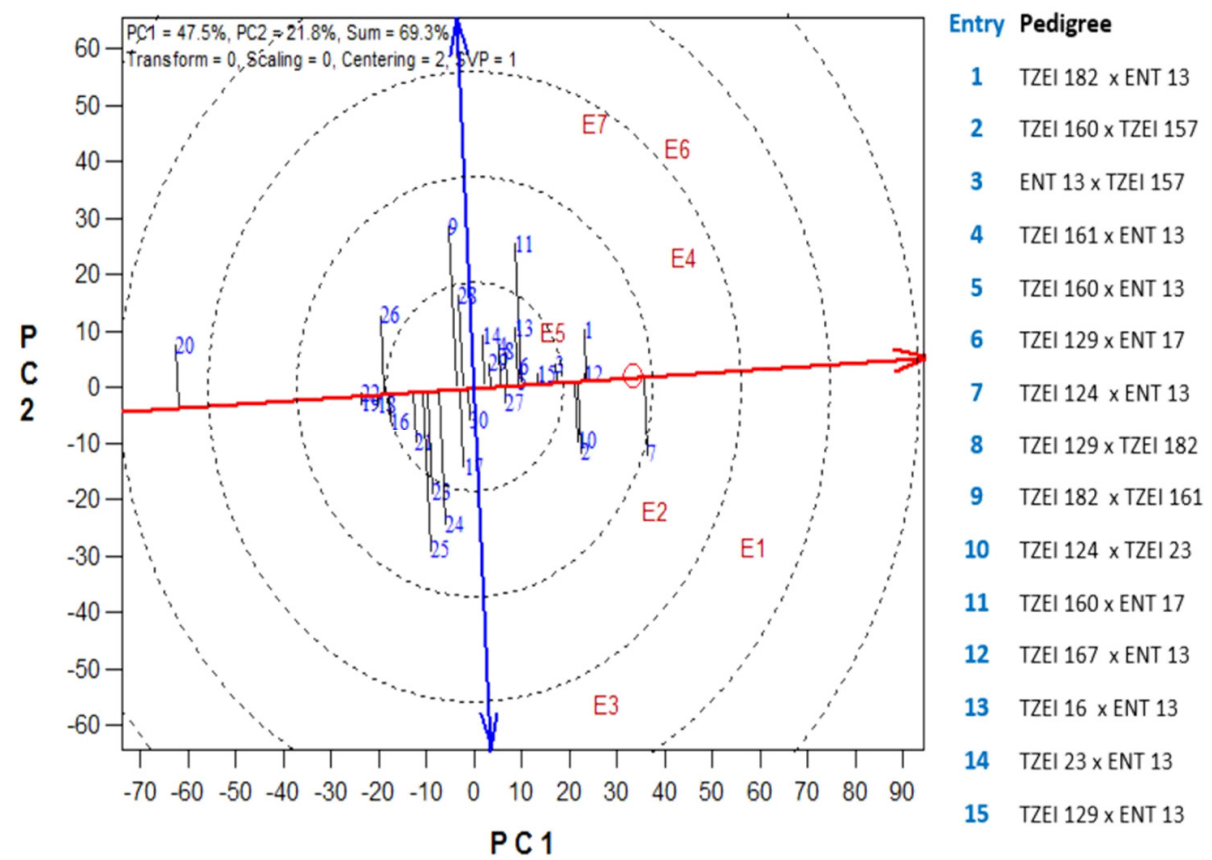

\section{Entry Pedigree}

16 ENT $15 \times$ TZEI 167

17 TZEI $167 \times$ TZEI 124

18 ENT $15 \times$ ENT 17

19 TZEI $167 \times$ ENT 4

20 ENT $15 \times$ ENT 4

21 TZEI $124 \times$ TZEI 135

22 ENT $15 \times$ TZEI 14

23 ENT $17 \times$ TZEI 124

24 ENT $15 \times$ TZEI 124

25 TZEI $124 \times$ ENT 4

26 TZEQI $82 \times$ TZEQI 93 Chk

27 TZEI $23 \times$ TZEI $13 \mathrm{Chk}$

28 TZEI $16 \times$ TZEI 8 Chk

29 TZEI $9 \times$ TZEl 16 Chk

30 P3 Kolo Check

Figure 4. Mean performance and stability of 25 early maturing maize hybrids and 5 checks in terms of grain yield as measured by principal components across seven environments (E1 to E4: Well-watered environments; E5 to E7: drought + heat stressed environments).

The lowest yielding hybrids were ENT $15 \times$ ENT 4, ENT $15 \times$ TZEI 14 and TZEI $167 \times$ ENT 4 . The double- arrowed line is the average environment ordinate and points to greater variability or poorer stability in either direction. Therefore, hybrids TZEI $167 \times$ ENT 13 and ENT $13 \times$ TZEI 157 were the best hybrids in terms of stability and yield performance across the test environments. The hybrid, TZEI $124 \times$ ENT 13 was the most outstanding across test environments in terms of grain yield but was less stable than TZEI $167 \times$ ENT 13 . The single crosses TZEI $182 \times$ TZEI 161 and TZEI $124 \times$ ENT 4 were the most unstable in this study.

The best 25 hybrids selected using the base index and the five checks were subjected to the "which-won-where" function of the GGE biplot to determine the winning hybrids in one or more of the test environments (Figure 5). The perpendicular lines to the sides of the polygon are equality lines between adjacent genotypes in the polygon; they facilitate visual comparison among the genotypes. Figure 5 identified the winning hybrid for each sector of the polygon defined by the equality lines 
as the one located on the respective vertex. The seven environments were between three sectors. The single cross hybrid TZEI $124 \times$ ENT 13 (entry 7) was the best hybrid in terms of grain yield in the four well-watered environments (E1, E2, E3 and E4), while TZEI $182 \times$ ENT13 (entry 1) was the best hybrid in the three CDHS environments (E5, E6 and E7).

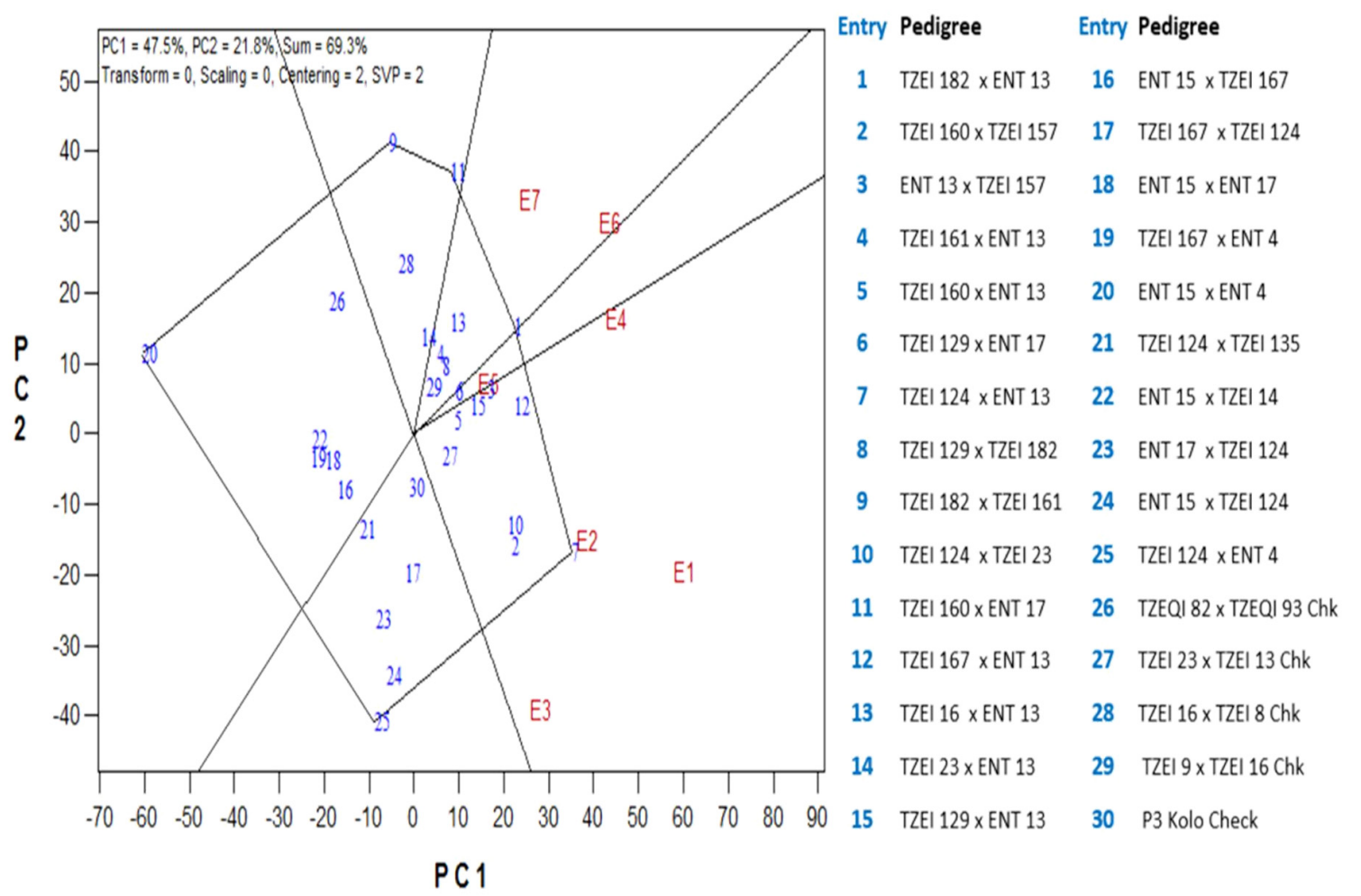

Figure 5. A "which won where" genotype main effect plus genotype $\times$ environment interaction (GGE) biplot of grain yield of 25 selected early maturing single cross hybrids and five checks evaluated across seven environments (E1 to E4: well-watered environments; E5 to E7: drought + heat stressed environments).

\subsection{Selection of the Best Hybrids under Drought Using the Base Index}

Traits proposed by Badu-Apraku et al. [58] in the computation of the base index (ASI, PASP, EASP, EPP and STGR2) were used to identify outstanding hybrids across CDHS environments. The outstanding hybrids under CDHS included TZEI $182 \times$ ENT $13(2753 \mathrm{~kg} / \mathrm{ha})$; TZEI $160 \times$ TZEI $157(2570 \mathrm{~kg} / \mathrm{ha})$; ENT $13 \times$ TZEI $157(2560 \mathrm{~kg} / \mathrm{ha})$; TZEI $161 \times$ ENT $13(2383 \mathrm{~kg} / \mathrm{ha})$ and TZEQI $82 \times$ TZEQI 93 check $(2309 \mathrm{~kg} / \mathrm{ha})$. The top three hybrids out yielded the best CDHS tolerant check TZEQI $82 \times$ TZEQI 93 by 19.2, 11.3 and 10.8\%, respectively (Table 4). Across WW environments, the five most outstanding hybrids in terms of grain yield included TZEI $124 \times$ ENT $13(6584 \mathrm{~kg} / \mathrm{ha})$, TZEI $124 \times$ TZEI 23 (5806 kg/ha), TZEI $160 \times$ TZEI 157 (5708 kg/ha), ENT $13 \times$ TZEI 157 (5454 kg/ha) and TZEI $182 \times$ ENT $13(5416 \mathrm{~kg} / \mathrm{ha})$. The three top-yielding hybrids, TZEI $124 \times$ ENT 13, TZEI $124 \times$ TZEI 23 and TZEI $160 \times$ TZEI 157 across WW environments out yielded the best hybrid check, TZEI $23 \times$ TZEI $13(5063 \mathrm{~kg} / \mathrm{ha}$ ) by 30,14.7 and 12.7\%, respectively (Table 4). Grain yield of the single cross hybrids across CDHS was $1684 \mathrm{~kg} / \mathrm{ha}$ while the average yield across well-watered environments was 4571 $\mathrm{kg} / \mathrm{ha}$ (Table 4). The intensity of the CDHS estimated as the ratio of the average grain yield of the moisture stress environments to that of the WW environments was $36.84 \%$. 
Table 4. Grain yield and other traits of hybrids (the best 10 and the worst 10 based on base index) and checks (Chk) evaluated under combined drought and heat stress (CDHS) and well-watered environments (WW) in Niger from 2012 to 2014.

\begin{tabular}{|c|c|c|c|c|c|c|c|c|c|c|c|c|c|c|c|c|}
\hline \multirow[t]{2}{*}{ Hybrids } & \multicolumn{2}{|c|}{$\begin{array}{l}\text { Grain Yield } \\
\text { (Kg/ha) }\end{array}$} & \multicolumn{2}{|c|}{ Days to Silking } & \multicolumn{2}{|c|}{$\begin{array}{l}\text { Anthesis-Silkiing } \\
\text { Interval }\end{array}$} & \multicolumn{2}{|c|}{$\begin{array}{l}\text { Plant Height } \\
\text { (cm) }\end{array}$} & \multicolumn{2}{|c|}{$\begin{array}{l}\text { Plant } \\
\text { Aspect }\end{array}$} & \multicolumn{2}{|c|}{$\begin{array}{l}\text { Ears per } \\
\text { Plant }\end{array}$} & \multicolumn{2}{|c|}{ Ear Aspect } & \multirow{2}{*}{$\begin{array}{c}\begin{array}{c}\text { Stay Green } \\
\text { Characteristic } \\
\text { (100 DAP) }\end{array} \\
\text { CDHS }\end{array}$} & \multirow[t]{2}{*}{$\begin{array}{l}\text { Base } \\
\text { Index }\end{array}$} \\
\hline & WW & CDHS & WW & CDHS & WW & CDHS & WW & CDHS & WW & CDHS & WW & $\mathrm{CDH}$ & SWW & CDHS & & \\
\hline TZEI $182 \times$ ENT 13 & 5416 & 2753 & 58 & 72 & 1 & 5 & 189 & 158 & 2.6 & 2.7 & 1.1 & 1.0 & 2.2 & 2.9 & 6.0 & 5.1 \\
\hline TZEI $160 \times$ TZEI 157 & 5708 & 2570 & 57 & 72 & 1 & 5 & 182 & 157 & 2.8 & 3.0 & 1.2 & 1.1 & 2.5 & 3.0 & 6.7 & 4.4 \\
\hline ENT $13 \times$ TZEI 157 & 5454 & 2560 & 60 & 75 & 1 & 6 & 195 & 161 & 2.1 & 2.7 & 1.2 & 1.0 & 2.0 & 2.9 & 5.5 & 4.4 \\
\hline TZEI 161 × ENT 13 & 4854 & 2383 & 57 & 73 & 0 & 4 & 182 & 150 & 2.8 & 2.8 & 1.2 & 1.0 & 2.5 & 3.1 & 6.5 & 3.9 \\
\hline $\begin{array}{c}\text { TZEQI } 82 \times \text { TZEQI } 93 \\
\text { (Chk) }\end{array}$ & 3792 & 2309 & 65 & 78 & 2 & 4 & 175 & 147 & 2.9 & 2.3 & 1.0 & 1.0 & 3.3 & 3.5 & 5.2 & 3.8 \\
\hline TZEI $160 \times$ ENT 13 & 5190 & 2222 & 57 & 73 & -1 & 5 & 172 & 149 & 2.9 & 2.8 & 1.2 & 1.2 & 2.3 & 3.3 & 7.7 & 3.8 \\
\hline TZEI $129 \times$ ENT 17 & 5141 & 2399 & 60 & 75 & 1 & 4 & 191 & 156 & 3.0 & 3.0 & 1.2 & 1.0 & 2.2 & 3.1 & 6.2 & 3.8 \\
\hline TZEI $124 \times$ ENT 13 & 6584 & 1993 & 58 & 77 & 1 & 5 & 194 & 164 & 1.1 & 2.7 & 1.1 & 1.0 & 1.4 & 2.8 & 6.0 & 3.5 \\
\hline TZEI $129 \times$ TZEI 182 & 4915 & 2216 & 58 & 77 & 1 & 6 & 176 & 144 & 3.3 & 3.2 & 1.1 & 1.2 & 2.4 & 3.1 & 6.0 & 3.5 \\
\hline TZEI $182 \times$ TZEI 161 & 4045 & 2401 & 58 & 71 & 2 & 4 & 166 & 145 & 3.4 & 3.2 & 1.1 & 1.1 & 2.8 & 3.4 & 4.7 & 3.5 \\
\hline TZEI $124 \times$ TZEI 23 & 5806 & 1897 & 56 & 70 & 1 & 5 & 170 & 151 & 2.5 & 2.8 & 1.1 & 1.1 & 2.2 & 2.9 & 6.3 & 3.4 \\
\hline TZEI $23 \times$ TZEI 13 (Chk) & 5063 & 1992 & 59 & 76 & 1 & 4 & 168 & 134 & 2.9 & 3.3 & 1.3 & 1.1 & 2.7 & 3.5 & 6.5 & 2.3 \\
\hline TZEI $16 \times$ TZEI 8 (Chk) & 4423 & 2008 & 59 & 76 & 1 & 7 & 156 & 135 & 2.8 & 3.2 & 1.2 & 1.0 & 2.8 & 3.4 & 7.3 & 1.4 \\
\hline TZEI $9 \times$ TZEI 16 (Chk) & 4981 & 1835 & 59 & 76 & 1 & 7 & 164 & 144 & 2.5 & 3.5 & 1.1 & 1.0 & 2.4 & 3.6 & 7.0 & 0.2 \\
\hline P3 Kolo (Chk) & 4690 & 1439 & 55 & 70 & 1 & 6 & 172 & 156 & 3.0 & 3.8 & 1.3 & 0.9 & 2.9 & 4.1 & 6.8 & -1.7 \\
\hline ENT $15 \times$ TZEI 167 & 4354 & 1069 & 64 & 82 & 3 & 9 & 175 & 137 & 3.0 & 4.3 & 1.1 & 0.9 & 2.7 & 4.2 & 7.3 & -3.8 \\
\hline TZEI $167 \times$ TZEI 124 & 5149 & 1200 & 61 & 79 & 1 & 11 & 193 & 153 & 2.1 & 4.0 & 1.1 & 0.7 & 2.1 & 4.0 & 7.8 & -4.0 \\
\hline ENT 15 × ENT 17 & 4043 & 984 & 61 & 82 & 1 & 8 & 183 & 139 & 3.1 & 4.3 & 1.1 & 0.7 & 2.6 & 4.1 & 7.5 & -4.4 \\
\hline TZEI $167 \times$ ENT 4 & 3996 & 952 & & 82 & 3 & 8 & 174 & 138 & 3.0 & 4.3 & 1.0 & 0.8 & 2.5 & 4.4 & 7.7 & -4.5 \\
\hline ENT $15 \times$ ENT 4 & 2021 & 594 & 66 & 84 & 2 & 7 & 167 & 131 & 4.4 & 4.3 & 1.0 & 0.8 & 3.4 & 4.2 & 7.2 & -4.8 \\
\hline TZEI $124 \times$ TZEI 135 & 4634 & 949 & 60 & 81 & 2 & 10 & 187 & 154 & 2.8 & 4.2 & 1.1 & 0.7 & 2.3 & 4.2 & 7.2 & -5.0 \\
\hline ENT 15 × TZEI 14 & 4020 & 849 & 63 & 83 & 3 & 9 & 177 & 137 & 3.4 & 4.3 & 1.1 & 0.7 & 2.6 & 4.3 & 7.2 & -5.1 \\
\hline ENT $17 \times$ TZEI 124 & 4859 & 721 & 60 & 84 & 1 & 10 & 190 & 142 & 2.8 & 4.5 & 1.2 & 0.7 & 2.2 & 4.6 & 7.8 & -6.1 \\
\hline ENT $15 \times$ TZEI 124 & 5290 & 736 & 61 & 83 & 3 & 12 & 189 & 156 & 2.5 & 4.2 & 1.2 & 0.5 & 2.1 & 4.2 & 7.7 & -6.5 \\
\hline TZEI $124 \times$ ENT 4 & 5097 & 649 & 60 & 82 & 2 & 14 & 182 & 154 & 2.5 & 4.2 & 1.1 & 0.7 & 2.1 & 4.3 & 7.3 & -6.7 \\
\hline Grand mean & 4571 & 1684 & 60 & 76 & 1 & 7 & 174 & 145 & 3.0 & 3.5 & 1.1 & 0.9 & 2.6 & 3.7 & 6.5 & \\
\hline${ }^{*}$ LSD & 865 & 775 & 1.7 & 3.9 & 1.3 & 3.2 & 12 & 15 & 0.50 & 0.90 & 0.10 & 0.30 & 0.40 & 0.70 & 1.10 & \\
\hline
\end{tabular}




\subsection{Stepwise Multiple Regression and Sequential Path Analyses}

The results of the stepwise multiple regression analysis identified EASP, DS, PASP, TBLAST, EHT and LFR as the first order traits with significant direct contributions to the variations observed in grain yield, under CDHS environments (Figure 6). The identified traits contributed about $86 \%$ of the total variation in grain yield. The highest direct effect $(-0.873)$ on grain yield was detected for EASP while the LFR had the least contribution to grain yield (-0.102). Of the first order traits, only EHT showed significant negative direct effect on grain yield. Seven traits including PLTH, EPP, DA, STGR1, STGR2, HC and ASI were classified as second order traits. The DA displayed indirect effect on grain yield through the six first order traits, EPP through five, PLTH, STGR2 and ASI through four, HC through three and STGR1 through one trait. Six of the second order traits contributed to grain yield through EASP and PASP while the contribution of four other traits was through TBLAST, EHT and LFR and three traits through DS. Across well-watered environments, the six traits EASP, DS, PASP, EHT, EPP and ASI were identified as the first order traits which explained $91 \%$ of the variation in grain yield (Figure 7). The EASP had the highest direct effect (-0.867) on grain yield, followed by PASP, DS, EHT, EPP and ASI in that order. The second order traits included PLTH, DA and HC. Each of PLTH and DA indirectly influenced grain yield through four of the first order traits while HC had significant indirect contributions to grain yield through three of the first order traits. Three second order traits indirectly contributed to grain yield through EASP whereas two traits had indirect effects through each of the traits: DS, PASP, EHT and ASI.

Across test environments, the sequential path analyses revealed EASP, EHT, DS, PASP, PLTH and EPP as the first order traits, explaining $84 \%$ of the variation observed in grain yield (Figure 8 ). The EASP, DS and PASP had negative direct effects on grain yield while the effects of EHT, PLTH and EPP were positive. Like the observations under CDHS and WW research environments, EASP displayed the highest direct effect $(-0.722)$ on grain yield out of the six first order traits. It is striking that EPP recorded the least direct effect on grain yield. The DA, HC and ASI were identified as second order traits across test environments. The DA contributed to grain yield through three first order traits while ASI and HC indirectly contributed to grain yield through two and one first order traits, respectively. Two second order traits contributed to grain yield through DS and one each through EASP, EHT, PASP and EPP. No second order trait contributed to grain yield through PLTH. 


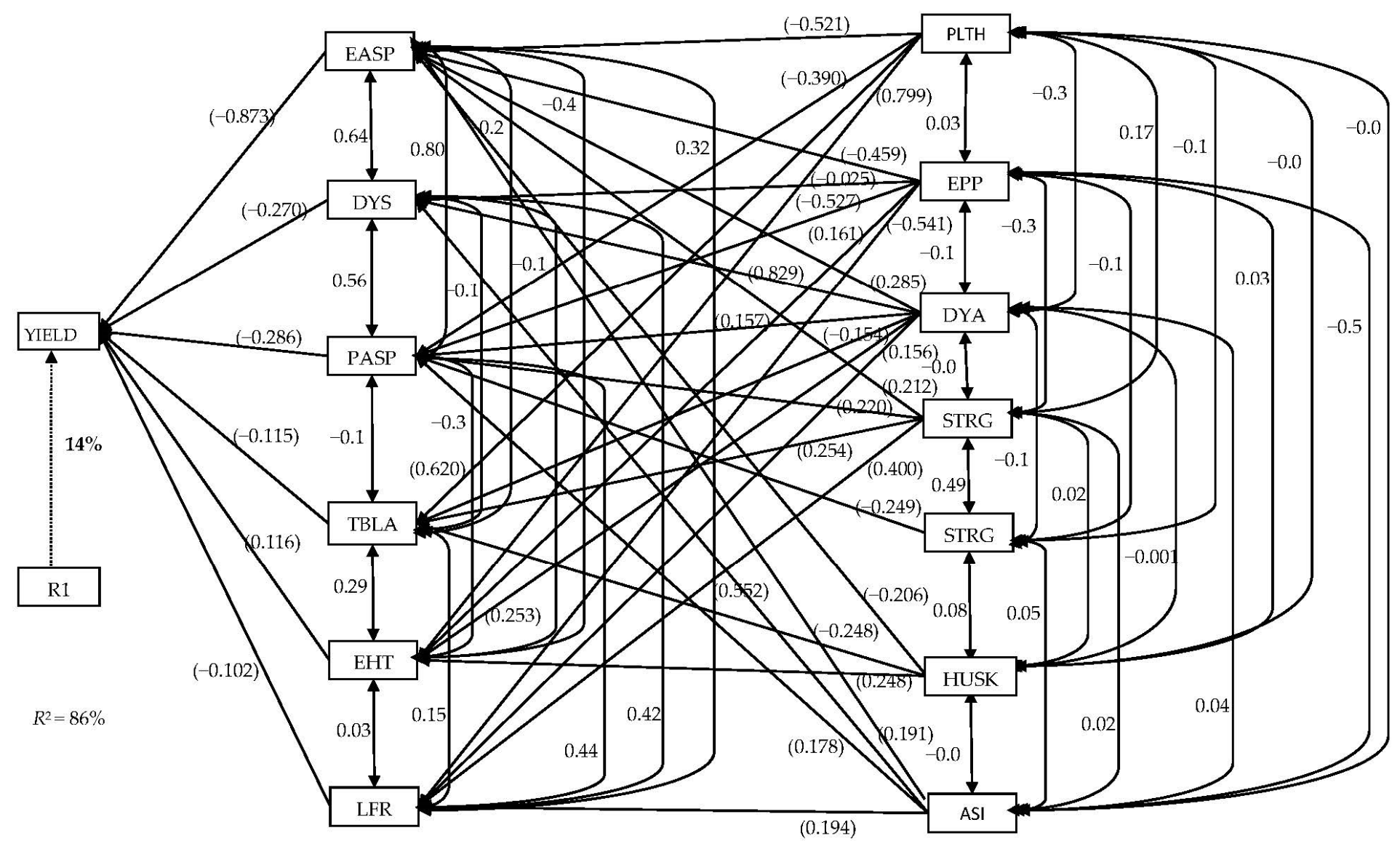

Figure 6. Path analysis model diagram showing causal relationships of measured traits of 105 early maturing yellow endosperm hybrids plus 5 checks evaluated under three combined drought and heat stress environments in Niger, 2012 to 2014 . Bold value is the residual effect; values in parenthesis are direct path coefficients while other values are correlation coefficients. R1 is residual effects; ASI, anthesis-silking interval; DYA, days to 50\% anthesis; DYS, days to 50\% silking; EHT, ear height; EASP, ear aspect; EPP, ears per plant; HUSK, husk cover; LFR, leaf firing; PASP, plant aspect; PLTH, plant height; STGR1, stay green characteristics (90 DAP); STGR2, stay green characteristics (100 DAP); TBLAST, tassel blast and YIELD, grain yield. 


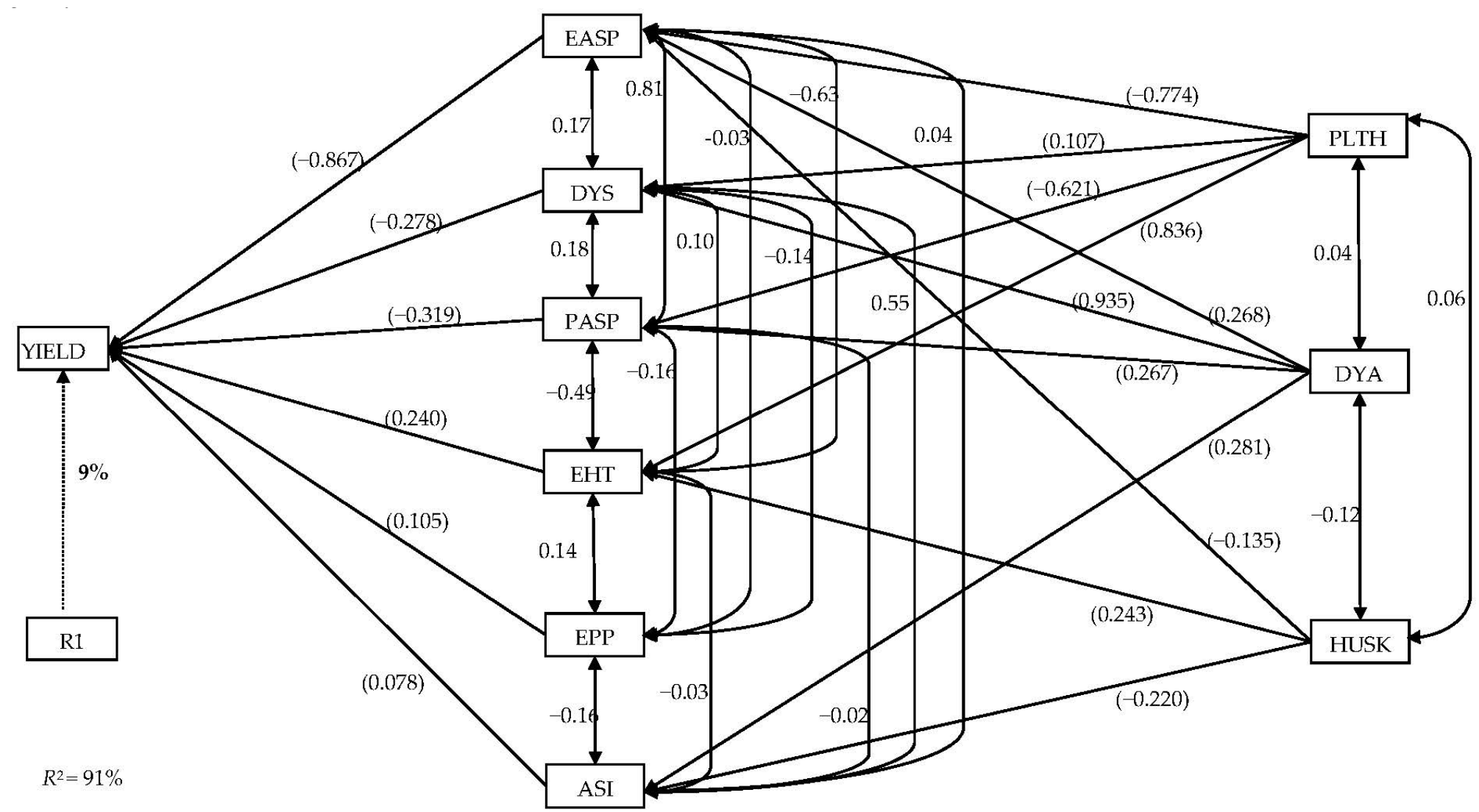

Figure 7. Path analysis model diagram showing causal relationships of measured traits of 105 early maturing yellow endosperm hybrids plus 5 checks evaluated under four well-watered environments in Niger, 2012 to 2014. Bold value is the residual effect; values in parenthesis are direct path coefficients while other values are correlation coefficients. R1 is residual effects; ASI, anthesis-silking interval; DYA, days to 50\% anthesis; DYS, days to 50\% silking; EHT, ear height; EASP, ear aspect; EPP, ears per plant; HUSK, husk cover; PASP, plant aspect; PLTH, plant height; and YIELD, grain yield. 


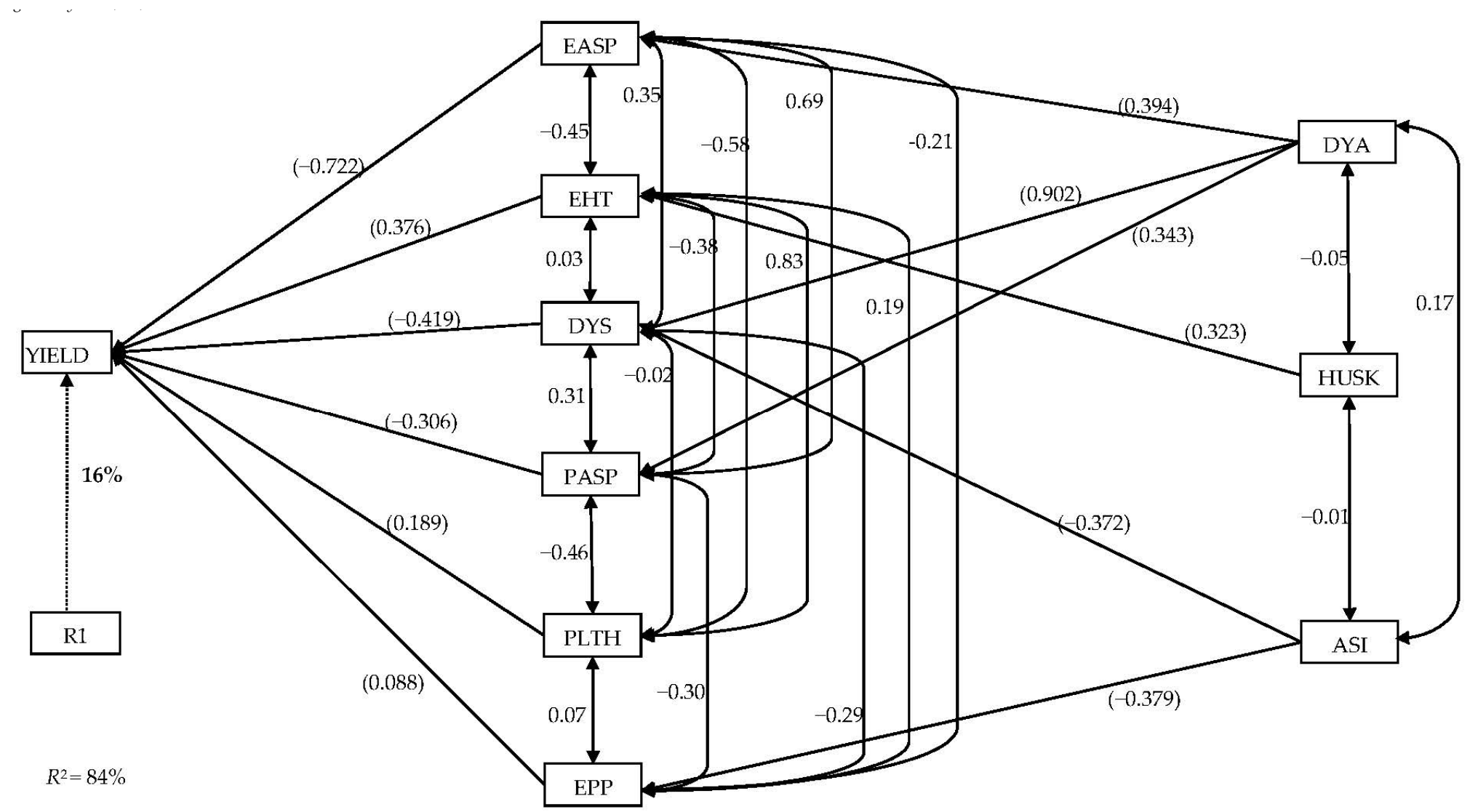

Figure 8. Path analysis model diagram showing causal relationships of measured traits of 105 early maturing yellow endosperm hybrids plus 5 checks evaluated across seven test environments in Niger, 2012 to 2014. Bold value is the residual effect; values in parenthesis are direct path coefficients while other values are correlation coefficients. R1 is residual effects; ASI, anthesis-silking interval; DYA, days to 50\% anthesis; DYS, days to 50\% silking; EHT, ear height; EASP, ear aspect; EPP, ears per plant; HUSK, husk cover; PASP, plant aspect; PLTH, plant height; and YIELD, grain yield. 


\section{Discussion}

The presence of significant mean squares for grain yield and the associated traits separately under CDHS and WW research environments indicated the existence of substantial genetic variability among the hybrids for the measured traits to allow significant progress from selection for the traits under the different environments. The significant environment mean squares observed for grain yield and most other traits under CDHS as well as WW environments indicated that the test environments were different. This result is important for assessing the performance and stability of the single cross hybrids in contrasting environments. However, there is a need for extensive evaluation of the hybrids in more environments over years to draw solid inferences about hybrid yield performance and stability. The significant genotype $\times$ environment interaction effects observed for grain yield and associated traits under CDHS and WW environments indicated the need for extensive testing of hybrids in multiple environments over years before recommendations could be made. Similar findings have been reported for early maturing tropical maize genotypes under contrasting environments by several researchers $[7,58]$.

A primary objective of this study was to investigate the combining ability of fifteen early maturing inbreds for grain yield and other agronomic traits under CDHS and WW environments. Statistically significant GCA and SCA effects detected for grain yield and most other measured agronomic traits under the two contrasting research conditions revealed that both additive and non-additive genetic effects were crucial to the inheritance of the traits. However, the GCA $\times$ Environment interaction mean squares for grain yield and all other traits under CDHS and WW environments also were significant indicating that GCA effects associated with parents were not consistent over environments. This suggested the use of inbreds as desirable parents for the development of hybrids and synthetics that should be recommended for specific environments. The preponderance of the GCA over the SCA mean squares of grain yield and other measured traits across test environments indicated that additive gene action was the most important in the inheritance of all the measured traits and that the observed differences among the single cross hybrids were principally attributable to the effects of the GCA.

Moreover, the preponderance of GCA over SCA effects suggested that the testing of early generation progenies may be successful and promising hybrids may be identified and selected based largely on the prediction from GCA effects. Nevertheless, the prediction of hybrid performance based on GCA effects of the parents alone will not always be sufficient since SCA effects were also significant. For example, even though the hybrid TZEI $160 \times$ TZEI 157 was derived from inbreds with low GCA effects, it was the third best performing hybrid across well-watered environments and the second highest yielding across CDHS environments. The present results are consistent with those of Betràn et al. [59] and Badu-Apraku et al. [60] who reported that additive gene action mainly contributed to the inheritance of grain yield under drought and well-watered conditions. Our results are also in agreement with the findings of other researchers $[7,40,41,61,62]$. However, these results disagree with those of Badu-Apraku et al. [45] who reported minor importance of GCA effects for grain yield and over dominating SCA effects in a diallel study involving nine early maturing yellow inbred lines under drought stress. The differences in these results could be attributed to the variations in the germplasm used as well as the climatic and soil conditions. The predominance of the additive genetic effects compared to the non-additive genetic effects in the present study suggested that additive gene action largely modulated the inheritance of the studied traits under both CDHS and WW. The implication is that the yield of the maize hybrids under moisture deficit could be enhanced through recurrent selection methods, such as the $\mathrm{S}_{1}$ family and the full-sib family selection schemes and that inbred lines tolerant to CDHS with high GCA effects could be extracted from improved cycles of selection of derived populations for hybrid development [63].

This result also indicated that substantial genetic enhancement could also be achieved by employing breeding schemes that capitalize on non-additive gene action, such as hybridization and pedigree selection. The implication is that selected inbred lines could be intercrossed to form heterotic 
populations which could be improved through recurrent selection methods, such as the $\mathrm{S}_{1}$ family and the full-sib family selection schemes. Subsequently, inbred lines tolerant to CDHS could then be extracted from improved cycles of selection of the populations and used for hybrid development.

The GCA effects of inbred lines are of crucial importance for the improvement of target traits in a population and for the development of synthetic varieties and hybrids [64]. The existence of positive and significant GCA effects for grain yield and negative and significant GCA effects for the stay green characteristic for inbreds ENT 13, TZEI 161 and TZEI 182 in the present study implied that significant progress had been made in developing CDHS tolerant maize hybrids and that the parental inbred lines possess genes for high grain yield and would delay the rate of leaf senescence in their progenies. Additionally, this result implied that the favorable alleles for these traits could be easily introgressed into tropical yellow maize populations for improving the yield performance of hybrids and synthetic varieties. The positive and significant GCA effects observed under CDHS of the three inbred lines, ENT 13, TZEI 161 and TZEI 182 implied that these lines had a high probability of transferring their characteristics to their progenies and could therefore serve as sources of favorable alleles for genetic enhancement of grain yield of tropical maize germplasm under CDHS conditions. High GCA indicates the inherent genetic value of a parent due to the presence of additive genetic effects and is fixable [65]. Therefore, the parental inbreds characterized by high GCA values for traits could produce superior segregants in the $\mathrm{F}_{2}$ and later generations as they could serve as vital sources of beneficial alleles [35]. Furthermore, the presence of high GCA effects for grain yield suggested that continued advancement could be made in selecting for increased grain yield.

Under well-watered environments, the highest, significant and positive GCA effects for grain yield were displayed by the inbred lines ENT 13, TZEI 124 and TZEI 129, suggesting a greater contribution of these inbred lines to the yield performance of their progenies under WW environments. The CIMMYT inbred ENT 13 had the highest significant and positive GCA effects for grain yield under CDHS and WW environments. It combined well with TZEI 124, TZEI 167 and TZEI 157. Furthermore, hybrids developed from this inbred line produced an average grain yield of $5214 \mathrm{~kg} \mathrm{ha}^{-1}$ under WW environments and $2110 \mathrm{~kg} \mathrm{ha}^{-1}$ under CDHS environments. It also ranked among inbreds with superior GCA effects for grain yield under low nitrogen and optimal growing environments as reported in an earlier study by Makumbi et al. [66]. Inbred ENT 13 was therefore the most outstanding general combiner. This inbred is presently an invaluable genetic resource for the development of hybrids and synthetics as well as for population improvement in SSA, since it contributed favorable alleles in the synthesis of new varieties [67]. The inbred lines TZEI 124 and TZEI 129 were also good combiners under well-watered environments based on their high and significant positive GCA effects for grain yield and outstanding grain yield $\left(>5000 \mathrm{~kg} \mathrm{ha}^{-1}\right)$ in hybrid combinations involving the inbreds under WW environments. However, these two inbred lines were very susceptible to CDHS, suggesting that hybrids derived from them are likely to suffer severe yield losses under combined drought and heat stress environments.

Another major focus of the present study was to identify superior hybrids in terms of grain yield and stability across contrasting environments. The GGE biplot analysis identified TZEI $124 \times$ ENT 13, TZEI $167 \times$ ENT 13, TZEI $182 \times$ ENT 13, TZEI $124 \times$ TZEI 23 and TZEI $160 \times$ TZEI 157 as the highest yielding hybrids across test environments. Among these five hybrids, TZEI $167 \times$ ENT 13 was the most stable across the contrasting environments. The hybrid had an above-average grain yield $\left(>5700 \mathrm{~kg} \mathrm{ha}^{-1}\right)$ across WW environments as well as under CDHS $\left(>2200 \mathrm{~kg} \mathrm{ha}^{-1}\right)$ suggesting that it should be extensively tested in on-farm trials to confirm the consistency of the yield performance under WW and CDHS prone environments and commercialized. The single cross hybrid, TZEI 124 $\times$ ENT 13 was outstanding in terms of grain yield performance under optimal growing conditions. However, this hybrid displayed significant yield reduction under CDHS probably because of the combined drought and heat stress susceptible parental inbred, TZEI 124. The hybrid TZEI $124 \times$ ENT 13 has been extensively tested in on-farm trials in Niger and already commercialized in high rainfall areas in Niger (Nasser, Personal communication, 2018). The single cross hybrid, TZEI $182 \times$ ENT 13 
was the best hybrid under the CDHS environments suggesting that it should be recommended to farmers who produce maize under rainfed conditions and whose production is frequently constrained by simultaneous occurrence of CDHS.

In the present study, a base index that integrated high grain yield under combined drought and heat stress along with desirable ASI, EPP, STGR, PASP and EASP was used to identify the outstanding hybrids under CDHS as well as WW environments (Table 4). The hybrids with combined tolerance to drought and heat stress were expected to suffer less yield reductions under stress as well as possess secondary traits strongly correlated with high grain yield under CDHS that is, reduced anthesis-silking interval, increased number of ears per plant, excellent plant aspect and ear aspect and delayed leaf senescence [2,62,68]. It is striking that the hybrids TZEI $182 \times$ ENT 13 and TZEI $160 \times$ TZEI 157 which were ranked as the best hybrids under combined drought and heat stress based on grain yield, were also identified as the top-yielding hybrids based on the selection index. This is a confirmation of the reliability of the IITA base index.

It is striking that the top-yielding hybrid under CDHS environments, TZEI $182 \times$ ENT 13 was derived from two drought tolerant inbreds. The outstanding performance of the hybrid under CDHS suggested a dosage effect of drought tolerance genes in the hybrid. This corroborated the findings of several authors $[2,59,60,68]$ who reported significant dosage effect under drought. The authors suggested the need to use drought tolerant lines as both parents of a hybrid to achieve acceptable drought tolerance under severe stress. Under WW environments, the most outstanding single cross hybrids included TZEI $124 \times$ ENT 13, TZEI $124 \times$ TZEI 23, TZEI $160 \times$ TZEI 157 and ENT $13 \times$ TZEI 157. Only the last two hybrids were identified among the five top-yielding hybrids under CDHS as well as under WW conditions.

In the present study the interrelationships among traits under CDHS, WW and across research environments were investigated. The identification of ear aspect, days to silking, plant aspect, tassel blasting, ear height and leaf firing as first order traits under CDHS indicated that these traits were key direct contributors to grain yield and could serve as indirect selection criteria for improved grain yield under CDHS environments. Traits such as EASP and PASP were also identified by Talabi et al. [57] as primary contributors to the variations in grain yield under drought stress as well as low soil nitrogen. Similarly, Badu-Apraku et al. [48] identified ear aspect, plant aspect, anthesis-silking interval and number of ears per plant as the important secondary traits for selection under drought stress. The identification of TBALST and LFR as first order traits implied that the two traits which are typically assayed under CDHS would be invaluable for selection for tolerance to combined drought and heat stress. Furthermore, the PLTH, EPP, DA, STGR1, STGR2, HC and ASI which were identified as second order traits could also be of potential value for selecting for improved grain yield under CDHS environments.

Although breeders select for superior performance of maize hybrids under stress conditions, the hybrids are also assessed under optimal growing environments to ascertain that the superior performance of such hybrids under stress environments demonstrated value addition when evaluated under optimal or non-stress environments. Therefore, the interrelationships among traits under WW environments are also as important to breeders as the yield performance under stress environments. The traits EASP, DS, PASP, EHT, EPP and ASI were the primary contributors to grain yield under WW environments. Our findings are consistent with those of Badu-Apraku et al. [48] who identified PLTH, EPP, PASP and EASP as reliable secondary traits under conditions where moisture and nitrogen were not limiting factors. Traits of primary importance across environments included EASP, EHT, DS, PASP, PLTH and EPP. It is striking that in the present study EASP, PASP, DS and EHT were consistently categorized as first order traits under each and across research environments. This implied that these traits in combination with grain yield could be useful for index selection for simultaneous improvement of grain yield under CDHS, WW and across different environments. Results of this study suggested that selection for ear height and/or plant height will improve grain yield. This may be done only under the CDHS conditions evaluated in the present study because the stresses normally reduce 
both plant and ear heights which are known to be positively correlated with grain yield in tropical maize. Thus, selection for taller plants under optimal production environments will increase lodging and may lead to low grain yield. The highest direct effect observed for EASP under each and across research environments in the present study indicated the importance of the trait as indirect selection criterion for grain yield across research environments. Talabi et al. [57] identified ear aspect as the primary contributor to grain yield under drought and low-N environments. Furthermore, the first order traits accounted for $86 \%, 91 \%$ and $84 \%$ of the variation in grain yield under CDHS, WW and across environments, respectively. This was an indication that the model was reliable in depicting the causal relationships among the traits under each and across research environments.

\section{Conclusions}

The drought tolerant inbred line ENT 13 was the most outstanding general combiner across research environments. Inbreds TZEI 124, TZEI 129 and ENT 13 were the most promising for hybrid development under WW environments while TZEI 182, TZEI 161 and ENT 13 were the best parents under CDHS environments. The drought tolerance genes from the outstanding inbreds could be introgressed into tropical breeding populations to improve grain yield under heat and drought stress and increase genetic diversity. The inbreds could also be used in hybrid combinations to develop outstanding drought and heat stress tolerant hybrids and synthetics. The best hybrids identified under WW environments included TZEI $124 \times$ ENT 13 and TZEI $124 \times$ TZEI 23 while TZEI $182 \times$ ENT 13 and TZEI $160 \times$ TZEI 157 were the most outstanding hybrids under CDHS environments. In addition, the hybrids TZEI $124 \times$ ENT 13, TZEI $167 \times$ ENT 13 and ENT $13 \times$ TZEI 157 were the highest yielding and most stable under the different environments. Thus, these outstanding hybrids should be extensively assessed on-farm in combined drought and heat stress environments and commercialized to improve food security in the dry savannas of SSA. The ear aspect could serve as an indirect selection criterion for improved grain yield under each and across research environments. Traits such as ear aspect, plant aspect and days to silking could be used in combination with grain yield in a selection index for simultaneous improvement of grain yield under combined heat and drought stress, well-watered and across test environments.

Author Contributions: Conceptualization, L.M.N., V.E.G. and B.B.-A.; Methodology, L.M.N., V.E.G. and B.B.-A.; Formal analysis, L.M.N.; Investigation, L.M.N., V.E.G. and B.B.-A., Resources, B.B.-A. and V.E.G.; Data curation, L.M.N.; Writing—original draft preparation, L.M.N. and B.B.-A.; Writing—review and editing, L.M.N., B.B.-A., V.E.G. and H.N.A.M.; Supervision, B.B.-A. and V.E.G.; Funding acquisition, V.E.G. and B.B.-A. All authors have read and agreed to the published version of the manuscript.

Funding: This work was supported by the Alliance for a Green Revolution in Africa and the Bill \& Melinda Gates Foundation [OPP1134248].

Acknowledgments: This work was supported by the Bill \& Melinda Gates Foundation [OPP1134248]. The authors are grateful to the staff of the International Institute of Tropical Agriculture Maize Program in Ibadan for the genetic materials and technical support. The financial support of the Alliance for a Green Revolution in Africa for this research is also gratefully acknowledged.

Conflicts of Interest: The authors declare no conflict of interest.

\section{References}

1. Gibbon, D.; Dixon, J.; Flores, D. Beyond Drought Tolerant Maize: Study of Additional Priorities in Maize; Report to Generation Challenge Program; CIMMYT Impacts, Targeting and Assessment Unit, CIMMYT: Ciudad de México, México, 2007.

2. Ribaut, J.; Betran, J.; Monneveux, P.; Setter, T. Drought Tolerance in Maize. In Handbook of Maize: Its Biology; Bennetzen, J.L., Hake, S.C., Eds.; Springer: New York, NY, USA, 2009; pp. 311-344.

3. Badu-Apraku, B.; Menkir, A.; Fakorede, M.A.B.; Kamara, A.Y.; Adam, A. Effects of Drought Screening Methodology on Genetic Variances and Covariances in Pool 16 DT Maize Population. J. Agric. Sci. 2004, 142, 445-452. [CrossRef] 
4. Badu-Apraku, B.; Lum, A.F. The Pattern of Grain Yield Response of Normal and Quality Protein Maize Cultivars in Stress and Non-stress Environments. Agron. J. 2010, 102, 381-394. [CrossRef]

5. Fischer, K.S.; Johnson, E.C.; Edmeades, G.O. Breeding and Selection for Drought Resistance in Tropical Maize. In Proceedings of the Symposium on Principles and Methods in Crop Improvement for Drought Resistance: With Emphasis on Rice, Mexico City, Mexico, 4-8 May 1982.

6. NeSmith, D.S.; Ritchie, J.T. Effects of Soil Water-deficit during Tassel Emergence on Development and Yield Components of Maize (Zea mays L.). Field Crop. Res. 1992, 28, 251-256. [CrossRef]

7. Pswarayi, A.; Vivek, B. Combining Ability Amongst CIMMYT's Early Maturing Maize (Zea mays L.) Germplasm under Stress and Non-stress Conditions and Identification of Testers. Euphytica 2008, 162, 353-362. [CrossRef]

8. Edmeades, G.O.; Chapman, S.C.; Bolaños, J.; Bänziger, M.; Lafitte, H.R. Recent Evaluations of Progress in Selection for Drought Tolerance in Tropical Maize. In Proceedings of the Fourth Eastern, Central and Southern African Regional Maize Conference, Harare, Zimbabwe, 28 March-1 April 1994; p. 89.

9. Fakorede, M.A.B.; Akinyemiju, O.A. Climatic Change: Effects of Maize Production in a Tropical Rainforest Location. In Maize Revolution in West and Central Africa, Proceedings of a Regional Maize Workshop, IITA—Cotonou, Benin, 14-8 May 2003; Badu-Apraku, B., Fakorede, M.A.B., Ouedraogo, M., Carsky, R.J., Menkir, A., Eds.; IITA: Cotonou, Benin Republic, 2003; pp. 272-282.

10. Adewale, S.A.; Akinwale, R.O.; Fakorede, M.A.B.; Badu-Apraku, B. Genetic Analysis of Drought-Adaptive Traits at Seedling Stage in Early-Maturing Maize Inbred Lines and Field Performance under Stress Conditions. Euphytica 2018, 214, 145. [CrossRef]

11. Grant, R.F.; Jackson, B.S.; Kiniry, J.R.; Arkin, G.F. Water Deficit Timing Effects on Yield Components in Maize. Agron. J. 1989, 81, 61-65. [CrossRef]

12. Monneveux, P.; Sanchez, C.; Beck, D.; Edmeades, G.O. Drought Tolerance Improvement in Tropical Maize Source Populations. Evidence of Progress. Crop Sci. 2006, 46, 180-191. [CrossRef]

13. Neilson, R.L. Assessing Effects of Drought on Corn Grain Yield; Purdue University: West Lafayette, IN, USA, 2007; Available online: http://www.kingcorn.org/news/article.07/drought-0705.html (accessed on 22 November 2019).

14. Meseka, S.; Menkir, A.; Bossey, B.; Mengesha, W. Performance Assessment of Drought Tolerant Maize Hybrids under Combined Drought and Heat Stress. Agronomy 2018, 8, 274. [CrossRef]

15. Cairns, J.E.; Crossa, J.; Zaidi, P.; Grudloyma, P.; Sanchez, C.; Araus, J.L.; Thaitad, S.; Makumbi, D.; Magorokosho, C.; Bänziger, M.; et al. Identification of Drought, Heat, and Combined Drought and Heat Tolerant Donors in Maize (Zea mays L.). Crop Sci. 2013, 53, 1335-1346. [CrossRef]

16. Lobell, D.B.; Burke, M.B. On the use of statistical models to predict crop yield responses to climate change. Agric. For. Meteorol. 2010, 150, 1443-1452. [CrossRef]

17. Badu-Apraku, B.; Fakorede, M.A.B. Advances in Genetic Enhancement of Early and Extra-Early Maize for Sub-Saharan Africa; Springer International Publishing AG: Cham, Switzerland, 2017.

18. Thompson, L.M. Weather variability, climatic change, and grain production. Science 1975, 188, 535-541. [CrossRef]

19. Badu-Apraku, B.; Hunter, R.B.; Tollenaar, M. Effect of during grain filling on whole plant and grain yield in maize (Zea mays L.). Can. J. Plant Sci. 1983, 63, 357-363. [CrossRef]

20. Muchow, R.C.; Sinclair, T.R.; Bennett, J.M. Temperature and solar radiation effects on potential maize yield across locations. Agron. J. 1990, 82, 338-343. [CrossRef]

21. Stone, P. The Effects of Heat Stress on Cereal Yield and Quality. In Crop Responses and Adaptations to Temperature Stress; Basara, A.S., Ed.; Food Products Press: Binghamton, NY, USA, 2001; pp. 243-291.

22. Crafts-Brander, S.J.; Salvucci, M.E. Sensitivity of photosynthesis in a C4 plant, maize, to heat stress. Plant Physiol. 2002, 129, 1773-1780. [CrossRef] [PubMed]

23. Schoper, J.B.; Lambert, R.J.; Vasilas, B.L. Pollen viability, pollen shedding and combining ability for tassel heat tolerance in maize. Crop Sci. 1987, 27, 27-31. [CrossRef]

24. Schoper, J.B.; Lambert, R.J.; Vasilas, B.L.; Westgate, M.E. Plant factors controlling seed set in maize: The influence of silk, pollen and ear-leaf water status and tassel heat treatment at pollination. Plant Physiol. 1987, 83, 121-125. [CrossRef]

25. Dupuis, I.; Dumas, C. Influence of temperature stress on in vitro fertilization and heat shock protein synthesis in maize (Zea mays L.) reproductive tissues. Plant Physiol. 1990, 94, 665-670. [CrossRef] [PubMed] 
26. Cicchino, M.; Edreria, J.I.R.; Uribelarrea, M.; Otegui, M.E. Heat Stress in Field-Grown Maize: Response of Physiological Determinants of Grain Yield. Crop Sci. 2011, 50, 1438-1448. [CrossRef]

27. Jagadish, K.S.V.; Cairn, J.E.; Kumar, A.; Somayanda, I.M.; Craufurd, P.Q. Does Susceptibility to Heat Stress Confound Screening for Drought Tolerance in Rice? Funct. Plant Biol. 2011, 38, 261-269. [CrossRef] [PubMed]

28. Vani, B.; Saradhi, P.P.; Mohanty, P. Alteration in Chloroplast Structure and Thylakoid Membrane Composition due to In-vitro Heat Treatment of Rice Seedlings: Correlation with the Functional Changes. J. Plant Physiol. 2001, 158, 583-592. [CrossRef]

29. Contarero, M.G.; Cirilo, A.G.; Andrade, F.H. Night Temperature at Silking affects Kernel Set in Maize. Crop Sci. 1999, 39, 701-710.

30. Pradhan, G.P.; Prasad, P.W.; Fritz, A.K.; Kirkham, M.B.; Gill, B.S. Effects of Drought and High Temperature Stress on Synthetic Hexaploid Wheat. Funct. Plant Biol. 2012, 39, 190-198. [CrossRef] [PubMed]

31. Lobell, D.B.; Bänziger, M.; Magorokosho, C.; Vivek, B. Nonlinear Heat Effects on African Maize as Evidenced by Historical Yield Trials. Nat. Clim. Chang. 2011, 1, 42-45. [CrossRef]

32. Niang, I.; Ruppel, O.C.; Abdrabo, M.A.; Essel, A.; Lennard, C.; Padgham, J.; Urquhart, P. Africa. In Climate Change 2014: Impacts, Adaptation, and Vulnerability. Part B: Regional Aspects. Contribution of Working Group II to the Fifth Assessment Report of the Intergovernmental Panel on Climate Change; Barros, V.R., Field, C.B., Dokken, D.J., Mastrandrea, M.D., Mach, K.J., Bilir, T.E., Chatterjee, M., Ebi, K.L., Estrada, Y.O., Genova, R.C., Eds.; Cambridge University Press: Cambridge, UK; New York, NY, USA, 2014.

33. Edmeades, G.O. Drought Tolerance in Maize: An Emerging Reality. A Feature in James, Clive. Global Status of Commercialized Biotech/GM Crops; International Service for the Acquisition of Agri-Biotech Applications (ISAAA) Brief No. 39; ISAAA: Ithaca, NY, USA, 2008; p. 8.

34. Campos, H.; Cooper, M.J.; Habben, E.; Edmeades, G.O.; Schussler, J.R. Improving Drought Tolerance in Maize: A View from Industry. Field Crop. Res. 2004, 90, 19-34. [CrossRef]

35. Nelimor, C.; Badu-Apraku, B.; Tetteh, A.Y.; N'guetta, A.S.P. Assessment of Genetic Diversity for Drought, Heat and Combined Drought and Heat Stress Tolerance in Early Maturing Maize Landraces. Plants 2019, 8 , 518. [CrossRef]

36. Panhwar, S.A.; Baloch, M.J.; Jatoi, W.A.; Veesar, N.F.; Majeedano, M.S. Combining ability estimates from line x tester mating design in upland cotton. Pak. Acad. Sci. 2008, 45, 69-74.

37. Elmyhun, M.; Liyew, C.; Shita, A.; Andualem, M. Combining ability performance and heterotic grouping of maize (Zea mays) inbred lines in testcross formation in Western Amhara, North West Ethiopia. Cogent Food Agric. 2020, 6, 1727625. [CrossRef]

38. Oyekunle, M.; Badu-Apraku, B.; Hearne, S.; Franco, J. Genetic diversity of tropical early-maturing maize inbreds and their performance in hybrid combinations under drought and optimum growing conditions. Field Crop. Res. 2015, 170, 55-65. [CrossRef]

39. Akinwale, R.O.; Badu-Apraku, B.; Fakorede, M.A.B.; Vroh-Bi, I. Heterotic grouping of tropical early-maturing maize inbred lines based on combining ability in Striga-infested and Striga-free environments and the use of SSR markers for genotyping. Field Crop. Res. 2014, 156, 48-62. [CrossRef]

40. Oyekunle, M.; Badu-Apraku, B. Genetic analysis of grain yield and other traits of early-maturing maize inbreds under drought and well-watered conditions. J. Agron. Crop Sci. 2014. [CrossRef]

41. Derera, J.; Tongoona, P.; Vivek, B.S.; Laing, M.D. Gene Action Controlling Grain Yield and Secondary Traits in Southern African Maize Hybrids under Drought and Non-drought Environments. Euphytica 2008, 162, 411-422. [CrossRef]

42. Librando, R.P.; Magulama, E.E. Classifying White Inbred Lines into Heterotic Groups Using Yield Combining Ability Effects. USMR DJ 2008, 16, 99-103.

43. Kanyamasoro, M.G.; Karungi, J.; Asea, G.; Gibson, P. Determination of the Heterotic Groups of Maize Inbred Lines and the Inheritance of their Resistance to the Maize Weevil. Afr. Crop Sci. J. 2012, 20, 99-104.

44. Badu-Apraku, B.; Fontem, L.A.; Akinwale, R.O.; Oyekunle, M. Biplot Analysis of Diallel Crosses of Early Maturing Tropical Yellow Maize Inbreds in Stress and Non-stress Environments. Crop Sci. 2011, 51, 173-188. [CrossRef]

45. Badu-Apraku, B.; Oyekunle, M.; Akinwale, R.O.; Aderounmu, M. Combining Ability and Genetic Diversity of Extra-early White Maize Inbreds under Stress and Non-stress environments. Crop Sci. 2013, 53, 9-26. [CrossRef] 
46. Bolaños, J.; Edmeades, G.O. The Importance of the Anthesis-silking Interval in Breeding for Drought Tolerance in Tropical Maize. Field Crop. Res. 1996, 48, 65-80. [CrossRef]

47. Badu-Apraku, B.; Fakorede, M.A.B.; Oyekunle, M.; Yallou, G.C.; Obeng-Antwi, K.; Haruna, A.; Usman, I.S.; Akinwale, R.O. Gains in Grain Yield of Early Maize Cultivars Developed during Three Breeding Eras under multiple environments. Crop Sci. 2015, 55, 527-539. [CrossRef]

48. Badu-Apraku, B.; Annor, B.; Oyekunle, M.; Akinwale, R.O.; Fakorede, M.A.B.; Talabi, A.O.; Akaogu, I.C.; Melaku, G.; Fasanmade, Y. Grouping of early maturing quality protein maize inbreds based on SNP markers and combining ability under multiple environments. Field Crop. Res. 2015, 183, 169-183. [CrossRef]

49. Snedecor, G.W.; Cochran, W.G. Statistical Methods, 8th ed.; Iowa State Univ Press: Ames, IA, USA, 1989.

50. Griffing, B. Concept of General and Specific Combining Ability in Relation to Diallel Crossing Systems. Aust. J. Biol. Sci. 1956, 9, 463-493. [CrossRef]

51. Zhang, Y.; Kang, M.S.; Lamkey, K.R. DIALLEL-SAS05: A Comprehensive Program for Griffing's and Gardner-Eberhart Analyses. Agron. J. 2005, 97, 1097-1106. [CrossRef]

52. Hung, H.Y.; Holland, J.B. Diallel Analysis of Resistance to Fusarium Ear Rot and Fumonisin Contamination in Maize. Crop Sci. 2012, 52, 2173-2181. [CrossRef]

53. Yan, W.; Tinker, N.A. Biplot Analysis of Multi-Environment Trial Data: Principles and Applications. Can. J. Plant Sci. 2006, 86, 623-645. [CrossRef]

54. Mohammadi, S.A.; Prasanna, B.M.; Singh, N.N. Sequential Path Model for Determining Interrelationships among Grain Yield and Related Characters in Maize. Crop Sci. 2003, 43, 1690-1697. [CrossRef]

55. SPSS Inc. SPSS Base 17.0 for Windows User's Guide; SPSS Inc.: Chicago, IL, USA, 2007.

56. Badu-Apraku, B.; Akinwale, R.O.; Oyekunle, M. Efficiency of Secondary Traits in Selecting for Improved Grain Yield in Extra-early Maize under Striga-infested and Striga-free Environments. Plant Breed. 2014, 133, 373-380. [CrossRef]

57. Talabi, A.O.; Badu-Apraku, B.; Fakorede, M.A.B. Genetic Variances and Relationship among Traits of an Early Maturing Maize Population under Drought-stress and Low Nitrogen Environments. Crop Sci. 2017, 57, 681-692. [CrossRef]

58. Badu-Apraku, B.; Akinwale, R.O.; Menkir, A.; Coulibaly, N.; Onyibe, J.E.; Yallou, G.C.; Abdullai, M.S.; Didjera, A. Use of GGE biplot for targeting early maturing maize cultivars to mega-environment in West Africa. Afr. Crop Sci. J. 2011, 19, 79-96. [CrossRef]

59. Betràn, F.J.; Beck, D.; Bänziger, M.; Edmeades, G.O. Genetic Analysis of Inbred and Hybrid Grain Yield under Stress and Non-stress Environments in Tropical Maize. Crop Sci. 2003, 43, 807-817. [CrossRef]

60. Badu-Apraku, B.; Oyekunle, M.; Akinwale, R.O.; Lum, A.F. Combining Ability of Early-maturing White Maize Inbreds under Stress and Non-stress Environments. Agron. J. 2011, 103, 544-557. [CrossRef]

61. Melani, M.D.; Carena, M.J. Alternative maize heterotic patterns for the northern corn belt. Crop Sci. 2005, 45, 2186-2194. [CrossRef]

62. Bolaños, J.; Edmeades, G.O. Eight Cycles of Selection for Drought Tolerance in Lowland Tropical Maize. II. Responses in Reproductive Behavior. Field Crop. Res. 1993, 31, 253-268. [CrossRef]

63. Obeng-Bio, E. Genetic Analysis of Grain Yield and Other Traits of Early Maturing Provitamin A-Quality Maize Inbred Lines under Drought and Low Soil Nitrogen Conditions. Ph.D. Thesis, University of Ghana, Accra, Ghana, 2018.

64. Lawson, D.J.; Falush, D. Population identification using genetic data. Annu. Rev. Genom. Hum. Genet. 2012, 13, 337-361. [CrossRef]

65. Badu-Apraku, B.; Yallou, C.; Obeng-Antwi, K.; Alidu, H.; Talabi, A.O.; Annor, B.; Oyekunle, M.; Akaogu, I.C.; Aderounmu, M. Yield gains in extra-early maize cultivars of three breeding eras under multiple environments. Agron. J. 2017, 109, 1-14. [CrossRef]

66. Makumbi, D.; Betrán, J.F.; Bänziger, M.; Ribaut, J. Combining Ability, Heterosis and Genetic Diversity in Tropical Maize (Zea mays L.) Under Stress and Non-stress Conditions. Euphytica 2011, 180, 143-162. [CrossRef] 
67. Badu-Apraku, B.; Oyekunle, M. Genetic Analysis of Grain Yield and other Traits of Extra-early Yellow Maize Inbreds and Hybrid Performance under Contrasting Environments. Field Crop. Res. 2012, 129, 99-110. [CrossRef]

68. Betràn, F.J.; Beck, D.; Bänziger, M.; Edmeades, G.O. Secondary Traits in Parental Inbreds and Hybrids under Stress and Non-stress Environments in Tropical Maize. Field Crop. Res. 2003, 83, 51-65. [CrossRef]

Publisher's Note: MDPI stays neutral with regard to jurisdictional claims in published maps and institutional affiliations.

(C) 2020 by the authors. Licensee MDPI, Basel, Switzerland. This article is an open access article distributed under the terms and conditions of the Creative Commons Attribution (CC BY) license (http://creativecommons.org/licenses/by/4.0/). 